Chicago-Kent College of Law

Scholarly Commons @ IIT Chicago-Kent College of Law

All Faculty Scholarship

Faculty Scholarship

February 1988

\title{
Separating the Strands in Separation of Powers Controversies
}

Harold J. Krent

IIT Chicago-Kent College of Law, hkrent@kentlaw.iit.edu

Follow this and additional works at: https://scholarship.kentlaw.iit.edu/fac_schol

Part of the Constitutional Law Commons

\section{Recommended Citation}

Harold J. Krent, Separating the Strands in Separation of Powers Controversies, 74 Va. L. Rev. 1258 (1988).

Available at: https://scholarship.kentlaw.iit.edu/fac_schol/340

This Article is brought to you for free and open access by the Faculty Scholarship at Scholarly Commons @ IIT Chicago-Kent College of Law. It has been accepted for inclusion in All Faculty Scholarship by an authorized administrator of Scholarly Commons @ IIT Chicago-Kent College of Law. For more information, please contact jwenger@kentlaw.iit.edu, ebarney@kentlaw.iit.edu. 


\title{
SEPARATING THE STRANDS IN SEPARATION OF POWERS CONTROVERSIES
}

\author{
Harold J. Krent*
}

\begin{abstract}
CASES involving separation of powers issues have proliferated in the last decade. Congressional efforts to streamline the adjudicative process, ${ }^{1}$ congressional endeavors to retain some control over Congress's broad delegations of authority to the executive branch, ${ }^{2}$ and increased executive branch sensitivities to perceived separation of powers infractions ${ }^{3}$ have perhaps all contributed to the growth of litigation. Public awareness of the litigation has in turn fostered additional challenges by a broad spectrum of private parties seeking to invalidate governmental action. ${ }^{4}$
\end{abstract}

*Assistant Professor of Law, University of Virginia. I would like to thank John Jeffries, Edmund Kitch, Michael Klarman, Peter Low, David Martin, Bill Stuntz, Alan Weiss, and Nicholas Zeppos for offering comments on an earlier draft. I would also like to thank William Aniskovich for his research assistance. Finally, as an attorney in the Department of Justice from 1983 to 1987, I participated in briefing several of the cases discussed in the Article. The views expressed in the Article, however, are my own.

1 See, e.g., Commodity Futures Trading Comm'n v. Schor, 478 U.S. 833 (1986) (congressional decision to vest jurisdiction over common law counterclaims in CFTC); Northern Pipeline Constr. Co. v. Marathon Pipe Line Co., 458 U.S. 50 (1982) (congressional effort to assign greater fact-finding roles to non-article III bankruptcy judges); United States v. Raddatz, 447 U.S. 667 (1980) (congressional decision to permit exercise of greater responsibility by magistrates who act as judicial adjuncts).

2 See, Bowsher v. Synar, 478 U.S. 714 (1986) (delegation of authority to Comptroller General, an officer removable at the initiative of Congress); INS v. Chadha, 462 U.S. 919 (1983) (exercise of a legislative veto over Immigration \& Naturalization Service ruling); American Fed'n of Gov't Employees v. Pierce, 697 F.2d 303 (D.C. Cir. 1982) (empowering committee of Congress to decide whether to permit the Department of Housing and Urban Development to proceed with a planned reorganization scheme).

${ }^{3}$ See, e.g., Benny v. England, 812 F.2d 1133 (9th Cir. 1987) (appointments clause challenge to status of bankruptcy judges under the Bankruptcy Amendments and Federal Judgeship Act of 1984); Ameron, Inc. v. United States Army Corps of Eng'rs, 809 F.2d 979 (3d Cir. 1986) (challenge to role of Comptroller General under Competition in Contracting Act), cert. granted, 108 S. Ct. 1218 (1988); Seattle Master Builders Ass'n v. Pacific Northwest Elec. Power and Conservation Planning Council, 786 F.2d 1359 (9th Cir. 1986) (appointments clause challenge to role of states in implementing national energy policy), cert. denied, $107 \mathrm{~S}$. Ct. 939 (1987).

4 See, e.g., Morrison v. Olson, 108 S. Ct. 2597 (1988) (rejecting challenge to delegation of prosecutorial authority to independent counsel who is appointed by special court and protected from the President's plenary removal authority); In re Sealed Case, 829 F.2d 50 
Although the issues and results in these cases have varied, the ensuing debate among commentators has largely turned on the distinction between a formalist and functionalist approach to resolving separation of powers questions. Those adhering to a formalist approach stress that the three branches of government should be kept as distinct as possible. ${ }^{5}$ Basing their approach loosely on the model of separation of powers discussed by Montesquieu, ${ }^{6}$ they argue that the key to separation of powers disputes lies in determining whether the challenged action should be characterized as lawmaking, in which case the power is to remain in the province of the legislature; as enforcing the law, in which case it is to remain the prerogative of the executive branch; or as interpreting the law, in which case it falls within the domain of the judiciary. ${ }^{7}$

In contrast, those adhering to a functionalist view of separation of powers eschew any reliance on the form of the particular action under challenge. They argue that, given the rise of the administrative state, it is impossible to distinguish the branches based on the type of acts they perform. Each branch acts in a variety of ways-making rules,

(D.C. Cir. 1987) (rejecting challenge to Attorney General's appointment of independent counsel), cert. denied, 108 S. Ct. 753 (1988); Ticor Title Ins. Co. v. FTC, 814 F.2d 731 (D.C. Cir. 1987) (challenge to enforcement role of Federal Trade Commission dismissed as unripe); Hospital Corp. of Am. v. FTC, 807 F.2d 1381 (7th Cir. 1986) (rejecting challenge to enforcement role of FTC), cert. denied, $107 \mathrm{~S}$. Ct. 1975 (1987); United States v. Woodley, 751 F.2d 1008 (9th Cir. 1985) (en banc) (rejecting challenge to recess appointment of article III judge), cert. denied, 475 U.S. 1048 (1986); Friedlander v. United States Postal Serv., 658 F. Supp. 95 (D.D.C. 1987) (rejecting challenge to exercise of executive responsibilities by Postal Service, an independent agency within the executive branch).

5 See M. Vile, Constitutionalism and the Separation of Powers 322-30 (1969).

6 C. Montesquieu, The Spirit of the Laws 149-82 (T. Nugent trans. 1949) (1st ed. 1750). Montesquieu, however, does not necessarily endorse such strict separation. See infra note 20.

7 See, e.g.s Langeluttig, Legal Status of the Comptroller General of the United States, 23 Ill. L. Rev. 556, 578-80 (1929). The Supreme Court, in Massachusetts v. Mellon, 262 U.S. 447 (1923), stated that

[t]o the legislative department has been committed the duty of making laws; to the executive the duty of executing them; and to the judiciary the duty of interpreting and applying them in cases properly brought before the courts. The general rule is that neither department may invade the province of the other and neither may control, direct or restrain the action of the other.

Id. at 488.

Few academics probably follow such a strict formalist approach today. Those adhering to a formalist approach, however, generally advocate delineating distinct spheres of authority among the branches. See, e.g., Burns \& Markman, Understanding Separation of Powers, 7 Pace L. Rev. 575, 578-85 (1987); Currie, The Distribution of Powers after Bowsher, 1986 Sup. Ct. Rev. 19, 31-36; Miller, Independent Agencies, 1986 Sup. Ct. Rev. 41, 44. 
interpreting rules, and applying them in a myriad of contexts. The functionalists, therefore, generally ask whether the exercise of the contested function by one branch impermissibly intrudes into the core function or domain of the other branch. ${ }^{8}$ In other words, as long as the power assumed by one branch does not threaten to disturb the basic allocation of powers intended by the framers, the action should be sustained.

This debate has mirrored divisions within the United States Supreme Court. There has been no uniform approach to separation of powers questions, and indeed, there appears to be substantial inconsistency. On the same day that the Court apparently adopted a formalist approach in striking down the Gramm-Rudman-Hollings Act in Bowsher v. Synar, ${ }^{9}$ it used a seemingly more flexible approach in Commodity Futures Trading Commission v. Schor, which upheld Congress's decision to vest in an administrative tribunal jurisdiction over common law claims. ${ }^{10}$

8 See, e.g., Banks \& Straussman, Bowsher v. Synar: The Emerging Judicialization of the Fisc, 28 B.C.L. Rev. 659, 684-86 (1987); Entin, The Removal Power and the Federal Deficit: Form, Substance, and Administrative Independence, 75 Ky. L.J. 699, $781-90$ (1987); Gifford, The Separation of Powers Doctrine and the Regulatory Agencies After Bowsher v. Synar, 55 Geo. Wash. L. Rev. 441, 444-45 (1987); Kurland, The Rise and Fall of the "Doctrine" of Separation of Powers, 85 Mich. L. Rev. 592, 602-03 (1986); Strauss, Formal and Functional Approaches to Separation-of-Powers Questions-A. Foolish Inconsistency?, 72 Cornell L. Rev. 488, 513 (1987); Note, Gramm-Rudman-Hollings: A Misapplication of Separation of Powers?, 9 U. Haw. L. Rev. 151, 181-86 (1987); Comment, Bowsher v. Synar: Bright-Line Rule or DiceToss Approach to Separation of Powers?, 38 Mercer L. Rev. 969, 985 (1987).

9478 U.S. 714 (1986) (citing Gramm-Rudman-Hollings Act, 2 U.S.C. $\S \S 901$ - 907 (Supp. IV 1986)).

10478 U.S. 833 (1986). In Northern Pipeline Constr. Co. v. Marathon Pipe Line Co., 458 U.S. 50 (1982), the Court had created substantial doubt as to whether such common law claims could be adjudicated by a non-article III federal tribunal.

Most commentators agree that the Court adopted a formalist approach in Bowsher but used a more functionalist approach in Schor. For instance, in the view of Professor Strauss:

In Bowsher, seven justices relied on formalism in rejecting Congress's work, over the vigorous protests of two dissenting functionalists. In Schor, seven functionalists-the Bowsher dissenters plus five of the majority in that case-sustained Congress's choice over a formalist dissent. Five justices, then, apparently wanted to have it both ways.

Strauss, supra note 8, at 489; see also Banks \& Straussman, supra note 8, at 687 n.271 (finding irony in the Court's announcement of the two seemingly irreconcilable decisions on the same day); Bruff, On the Constitutional Status of Administrative Agencies, 36 Am. U.L. Rev. 491, 501-03 (1987) (also characterizing Bowsher as formalist and Schor as functionalist); Comment, Independent Counsels Under the Ethics in Government Act of 1978: A Violation of the Separation of Powers Doctrine or an Essential Check on Executive Power?, 42 U. Miami L. Rev. 735, 759 (1988) (balancing approach in Schor was "completely distinct from the Court's 
In this Article, I will argue that the current debate between a formalist and functionalist approach is to a large measure misconceived. That debate obscures a deceptively simple principle underlying much of the Supreme Court's recent jurisprudence: that the Constitution circumscribes the power of the branches by limiting the ways each can act. Although the Constitution does not expressly address the allocation among the branches of the powers to make, interpret, and execute laws, ${ }^{11}$ it prescribes how and when each branch can act.

The constitutional restrictions on the manner in which the legislature can act are the most clearly defined. ${ }^{12}$ Congress can bind those outside its branch only by adhering to the bicameralism and presentment requirements in article I. Although the restraints on action circumscribing the other branches are not "procedural" in the same sense, they nonetheless serve an analogous function. For instance, the executive's ability to act is not unbounded-the executive's actions must generally comport with the terms set in legislative directives. Moreover, the executive is also checked by more specific restrictions in the Constitution such as the appointments clause in article II. Similarly, though not often thought of in the same vein, the "case or controversy" limitation in article III constrains the judiciary's mode of action. The judiciary for the most part can act only in the context of properly constituted cases and controversies.

The constitutional provisions circumscribing the ways all three branches can act ${ }^{13}$ serve in essence as a first-line defense of the separation of powers scheme-conflict among the branches can largely be

approach in Bowsher"). Professor Carter, in a recent article, suggests that the Supreme Court's cases reflect vacillation between an "evolutionary" and a "de-evolutionary" approach to separation of powers. See Carter, From Sick Chicken to Synar: The Evolution and Subsequent De-Evolution of the Separation of Powers, 1987 B.Y.U. L. Rev. 719, 722-43.

11 The Constitution does provide in article I that the legislative power is vested in Congress; in article II that the executive power is vested in the executive; and in article III that the judicial power is vested in the judiciary. There is no discussion, however, of what those terms actually mean.

12 For a discussion of these restrictions, see Bowsher, 478 U.S. at 714; Chadha, 462 U.S. at 919; Martin, The Legislative Veto and the Responsible Exercise of Congressional Power, 68 Va. L. Rev. 253 (1982); Scalia, The Legislative Veto: A False Remedy for System Overload, Reg., Nov.-Dec. 1979, at 19.

13 As discussed infra, the constitutional restraints on action do not apply to acts taken pursuant to any inherent source of authority, whether that source has a constitutional or common law basis. For example, when the branches act to govern themselves internally, the restraints on action are not applicable. See infra note 99 (the legislature); infra note 179 (the executive); infra note 227 (the judiciary). Similarly, Congress and the judiciary traditionally 
avoided by respecting the distinct modes of action prescribed in the Constitution. The constitutional restraints on action promote accountability and therefore serve to minimize direct confrontation among the branches. If one branch has acted outside the constitutionally prescribed means of conduct, no accommodation among the branches is required, and the controversy between the formalist and functionalist positions need not be resolved. ${ }^{14}$ Thus, separation of powers disputes can be approached under a two-step test. The initial question in assessing an asserted separation of powers violation is whether the branches have acted in accordance with the restraints on action prescribed in the Constitution. Only if a conflict among the branches is unavoidable must a court then tackle the frequently more difficult question of how to accommodate the overlapping powers of the branches.

Under this view, the apparent inconsistency between Bowsher and Schor disappears. When one branch, as in Schor, exercises authority in a manner that is procedurally proper but nonetheless intrudes on the domain of another branch, some accommodation must be reached. In Schor, Congress's legitimate interest in vesting the reparations proceedings in a non-article III forum unavoidably clashed with the federal judiciary's arguable interest in retaining jurisdiction over all common law claims brought before a federal tribunal. But, as in Bowsher, when Congress (or another branch) acts in other than the constitutionally prescribed manner, no pragmatic accommodation of competing interests is needed. Because Congress could have directly prescribed the budget cuts at issue in Bowsher, the dispositive question was in a sense procedural-whether the Comptroller General, an officer removable by Congress, could exercise that same authority. ${ }^{15}$ Recognizing that the branches must adhere to the constitutionally

exercise the contempt power without conforming to their respective constitutional restraints. See infra notes 99, 213.

14 Although this view can be characterized as a species of formalism, it is a formalism predicated on specific constitutional provisions and not on any Platonic notion of the ideal separation among the branches, nor on the view that certain functions are reserved exclusively to the separate branches. Cf. Carter, supra note 10, at 765-800 (stressing the importance of focusing on constitutional structure).

15 In this Article, I assume that the judiciary will and should continue to resolve at least some separation of powers disputes. Because our system of separated powers was designed chiefly to preserve individual liberty, see infra notes 20-24 and accompanying text, precluding review of all such claims would deny individuals the benefit of the structural protections in the Constitution. But see J. Choper, Judicial Review and the National Political Process 263-315 
prescribed modes of action not only avoids doctrinal confusion, but should also ease the difficult institutional role of the judiciary in resolving at least some separation of powers disputes. ${ }^{16}$

I address the constitutional framework of checks and balances in Part I, and suggest that the internal checks or procedural restrictions prescribed in the Constitution serve the important functions of restraining the authority of each branch and of promoting accountability. An examination of the debates surrounding the Constitutional Convention supports this interpretation. In Part II, I analyze several separation of powers disputes in light of this understanding of the constitutional scheme, focusing upon the restrictions that circumscribe the authority of Congress. I then more tentatively examine the comparable restraints on the other branches' ability to act. I conclude that the conflicting approaches to separation of powers issues manifested in Supreme Court decisions can largely be reconciled by considering the constitutional limits defining the ways each branch can act. Finally, in Part III, I discuss the Supreme Court's recent decision in the independent counsel case ${ }^{17}$ from the perspective of the analysis presented in this Article.

\section{The Constitutional Allocation of Powers AMONG THE BRANCHES}

The Constitution restricts the manner in which each branch can act. These limitations appear designed to preserve a balance among the branches and to promote governmental accountability. Although it would be extravagant to claim that we can learn the framers' "original" understanding of the separation of powers doctrine, ${ }^{18}$ the

(1980) (arguing that individuals have no cognizable interest in identity of government actor whose action gave rise to the injury).

16 There have been and will in all likelihood continue to be occasions in which the powers of the branches collide, and in which the courts are therefore faced with the delicate and difficult task of accommodating the powers of each. In this Article, I will not suggest how courts should best accomplish that complex task. I will argue, however, that courts need not enter that labyrinth in cases in which the branches have not acted in conformance with the Constitution's procedural requirements. By focusing on the way in which each branch has acted, courts can resolve one stratum of separation of powers disputes without engaging in ad hoc balancing and can thereby promote the values underlying the system of separated powers.

17 Morrison v. Olson, 108 S. Ct. 2597 (1988).

18 See Powell, Rules for Originalists, 73 Va. L. Rev. 659 (1987). Commentators have suggested, however, that we can better understand the "original" understanding of structural questions such as those implicating separation of powers, rather than more discrete issues such 
available historical materials are certainly consistent with, and indeed reinforce, the importance of delineating the distinct modes of action contemplated in the Constitution for the three branches of government. ${ }^{19}$

\section{A. Constitutional Framework}

The reification of separation of powers theory in the Constitution departed substantially from previous theoretical models. ${ }^{20}$ The focus in the Constitution is not so much on keeping the branches separate as on constructing a scheme of checks and balances. Although the powers of government are kept distinct for the most part, each branch is also to be accorded "the necessary constitutional means and personal motives to resist the encroachments of the others," 21 even if that permits one branch to participate in the functions of another. The framers made the branches interdependent, and the system of checks and balances evinces the intent to make each branch accountable to the other.

as the meaning of "due process." See Carter, Constitutional Adjudication and the Indeterminate Text: A Preliminary Defense of an Imperfect Muddle, 94 Yale L.J. 821, 847-48 (1985).

19 For general discussions of the framers' views, see D. Epstein, The Political Theory of the Federalist (1984); W. Gwyn, The Meaning of the Separation of Powers (1965); F. McDonald, Novus Ordo Seclorum: The Intellectual Origins of the Constitution (1985); G. Wood, The Creation of the American Republic, 1776-1787 (1969); Kramnick, Republican Revisionism Revisited, 87 Am. Hist. Rev. 629 (1982).

20 See G. Wood, supra note 19, at 150-52; Kurland, supra note 8, at 599-600. Separation of powers theory was hardly monolithic in the seventeenth and eighteenth centuries. In simplified form, at least three separate strands existed. First, some advocated separating the powers to promote efficiency. Vesting the power of executing or administering the law in a legislature with many representatives might invite delay, confusion, and inefficiency. The efficiency version was a blueprint for "good" government, not a means to promote individual liberty. See generally Banks, Efficiency in Government: Separation of Powers Reconsidered, 35 Syracuse L. Rev. 715, 718-20 (1984) (noting efficiency concerns of seventeenth and eighteenth century theorists). Second, as advocated most prominently by Locke and Montesquieu, many believed that separating the powers would promote "the rule of law." See J. Locke, The Second Treatise of Government $\S 142$ (J. Gough ed. 1947) (6th ed. 1764); C. Montesquieu, supra note 6, at 151-52. Combining the powers of government would invite corruption because legislators could entirely exempt themselves from the application or implementation of unjust laws. The rule of law theory therefore sought to constrain the discretion of individual government officials. See D. Epstein, supra note 19, at 127-30. Third, some commentators-including Montesquieu and Locke-argued that separating the branches of government would protect individual liberty by limiting each branch's authority. See W. Gwyn, supra note 19 , at $40-43$; M. Vile, supra note 5, at 61-63.

21 The Federalist No. 51, at 321-22 (J. Madison) (C. Rossiter ed. 1961). 
The constitutional scheme, however, also reflects interest in making the branches responsible to some higher public interest. ${ }^{22}$ The framers included checks and balances not only to prevent each branch from accumulating power at the expense of the others, but also to protect against the rule of "faction," primarily in the legislative branch. Madison, perhaps the leading spokesman for the Constitution, defined faction as "a number of citizens, whether amounting to a majority or minority of the whole, who are united and actuated by some common impulse of passion, or of interest, adverse to the rights of other citizens, or to the permanent and aggregate interests of the community." 23 Even if the branches were kept separate, representatives of the people could become captured by a spirit of faction or narrow-mindedness and exercise governmental authority at the expense of public liberty. ${ }^{24}$ Instead of striving only to maintain a "balanced" government, as had prior separation of powers theorists, Madison defended the scheme as a means of protecting individual liberty from arbitrary governance, even by the democratically elected legislature.

Thus, the constitutional structure places a premium on accountability among the branches and on responsibility to the public interest. Separation of powers issues, as they arise today, must therefore be addressed by examining not merely the separation model envisioned by classical theorists, but also the checks and balances that distinctively mark the governmental structure in the Constitution. More particularly, the "internal" checks in the Constitution circumscribing the manner in which each branch can act must also be understood as part of the overall effort to confine governmental authority and instill governmental responsibility.

22 "Responsibility" in this context is somewhat misleading because it does not reflect a purely democratic responsibility to the electorate, but refers to responsibility to a higher public good.

23 The Federalist No. 10, supra note 21, at 78 (J. Madison); see F. McDonald, supra note 19, at 162-66; Scanlan, The Federalist and Human Nature, 21 Rev. Pol. 657 (1959).

24 Despite giving "lip service" to the "rule of law" ideal, the framers were more concerned with curbing the legislature's power and preventing the ascendancy of "factions." See 1 The Records of the Federal Convention of 1787, at 108, 134-36 (M. Farrand rev. ed. 1966) [hereinafter Federal Convention Records] (statement of Madison); id. at 51 (statement of Randolph); id. at 254 (statement of Wilson); id. at 288-89 (statement of Hamilton); id. at 51112 (statement of Morris). But see D. Epstein, supra note 19, at 126-30 (arguing that Madison embraced "rule of law" theory); Sargentich, The Contemporary Debate About LegislativeExecutive Separation of Powers, 72 Cornell L. Rev. 430, 450-51 (1987) (same). 


\section{B. The Function of Constitutional Restraints on Action}

In light of the difficulty of ensuring a balance among the branches, the framers supplemented the general separation provided in the Constitution with more specific restrictions governing the ways each branch can act. ${ }^{25}$ To Madison, an effective system of separated powers could not be maintained merely by separating the branches, nor even by inserting "external" checks, such as the power of impeachment or the power of judicial review. He stated that "a mere demarcation on parchment of the constitutional limits of the several departments is not a sufficient guard against those encroachments which lead to a tyrannical concentration of all the powers of government in the same hands." 26 "[T]he boundaries of [the three] departments" outlined in the Constitution could not protect against "the encroaching spirit of power."27 Madison readily acknowledged that there was no functional way of separating the branches: "Experience has instructed us that no skill in the science of government has yet been able to discriminate and define, with sufficient certainty, its three great provinces-the legislative, executive, and judiciary; or even the ... powers of the different legislative branches." 28 Hamilton similarly observed that " $[t]$ he insufficiency of a mere parchment delineation of the boundaries of each [branch of government] has also been remarked upon."29

The goal of the constitutional scheme was therefore to "contriv[e] the interior structure of the government, as that its several constituent parts may, by their mutual relations, be the means of keeping each other in their proper places." 30 As Madison explained in the famous

25 Cf. 2 J. Story, Commentaries on the Constitution of the United States $\S 517$, at 1 (1833 ed.) ("Every government must include within its scope . . . the exercise of the three great powers .... The manner and extent, in which these powers are to be exercised ... constitute the great distinctions which are known in the forms of government.").

26 The Federalist No. 48, supra note 21, at 313 (J. Madison).

27 Id. at 308.

28 The Federalist No. 37, supra note 21, at 228 (J. Madison). During the Convention, Madison stated:

If a Constitutional discrimination of the departments on paper were a sufficient security to each ag[ainst] encroachments of the others, all further provisions would indeed be superfluous. But experience had taught us ... that it is necessary to introduce such a balance of powers and interests, as will guarantee the provisions on paper.

2 Federal Convention Records, supra note 24, at 77.

29 The Federalist No. 73, supra note 21, at 442 (A. Hamilton).

30 The Federalist No. 51, supra note 21, at 320 (J. Madison). 
passage from The Federalist No. 51,

It may be a reflection on human nature that such devices should be necessary to control the abuses of government. But what is government itself but the greatest of all reflections on human nature? If men were angels, no government would be necessary. If angels were to govern men, neither external nor internal controls on government would be necessary. In framing a government which is to be administered by men over men, the great difficulty lies in this: you must first enable the government to control the governed; and in the next place oblige it to control itself. A dependence on the people is, no doubt, the primary control on the government; but experience has taught mankind the necessity of auxiliary precautions. ${ }^{31}$

Those "auxiliary precautions" or internal controls are a unique contribution of our system. The scheme of separated powers is, to a certain extent, self-executing: by circumscribing the ways each branch can act, ${ }^{32}$ the Constitution attempts to minimize clashes among the branches.

\section{Restraints on the Legislature's Mode of Action}

Although the Constitution places checks on all three branches, it circumscribes the legislature most rigidly. This result is not surprising because an overriding goal of the framers in establishing a system of checks and balances was to limit the legislative power. Madison explained that "[i]n republican government, the legislative authority necessarily predominates" 33 because the authority to set rules and policy makes the legislature the most powerful branch. Experience under the Articles of Confederation and various state constitutions had painfully proven that such power was subject to abuse; $;^{34}$ as Madison stated, "The legislative department is everywhere extending the sphere of its activity and drawing all power in its impetuous

\footnotetext{
31 Id. at 322.

32 The Constitution does not address the potential ramifications of governmental failures to act, and there is apparently no evidence that the framers were specifically troubled by such possibilities. Rather, the restraints in the Constitution are aimed at the more likely source of conflict among the branches-action.

33 The Federalist No. 51, supra note 21, at 322 (J. Madison).

34 See F. McDonald, supra note 19, at 144-62, 173-79; M. Vile, supra note 5, at 138-47; G. Wood, supra note 19 , at $403-13$.
} 
vortex."35 In particular, state legislators constructed a variety of inflationary schemes to aid debtors to the detriment of creditors both overseas and within the states. Such legislation not only led to a general decline in confidence (particularly among the moneyed classes), but also led indirectly to social unrest. ${ }^{36}$ Madison further stressed that in light of Congress's "constitutional powers being at once more extensive, and less susceptible of precise limits, it can, with the greater facility, mask, under complicated and indirect measures, the encroachments which it makes on the co-ordinate departments."37 Indeed, Madison noted that "the legislative department alone has access to the pockets of the people." 38 Because of the inadequacy of circumscribing authority through a functionalist description of the powers to be exercised, the framers sought to restrain Congress through "internal" checks by circumscribing the ways it must act. ${ }^{39}$ Constructing safeguards internal to the legislature would check

35 The Federalist No. 48, supra note 21, at 309 (J. Madison). With respect to his own Virginia legislature, Jefferson even wrote that placing all three powers

in the same hands is precisely the definition of despotic government. It will be no alleviation that these powers will be exercised by a plurality of hands, and not by a single one. ... An elective despotism was not the government we fought for, but one which should not only be founded on free principles, but in which the powers of government should be so divided and balanced among several bodies of magistracy, as that no one could transcend their legal limits, without being effectually checked and restrained by the others.

T. Jefferson, Notes on the State of Virginia 214, reprinted in 3 The Writings of Thomas Jefferson 223-24 (P. Ford ed. 1894), quoted in The Federalist No. 48, supra note 21, at 310-11 (J. Madison).

36 F. McDonald, supra note 19 , at 175-77; G. Wood, supra note 19 , at 404-07.

37 The Federalist No. 48, supra note 21, at 310 (J. Madison); see also 1 Annals of Cong. 454 (J. Gales ed. 1789) (statement of Madison) ("[T]he legislative [branch] . . . is the most powerful, and most likely to be abused, because it is under the least control.").

38 The Federalist No. 48, supra note 21, at 310 (J. Madison).

39 Locke had previously argued that the principal means of limiting legislative power was to limit the manner in which the legislature could act. He wrote that "the legislative, or supreme authority, cannot assume to itself a power to rule by extemporary arbitrary decrees, but is bound to dispense justice, and decide the rights of the subject by promulgated standing laws." J. Locke, supra note 20, 136 ; see M. Vile, supra note 5, at 63 (arguing that, to Locke, "[t]he legislative authority is the authority to act in a particular way").

The Constitution, of course, also limits the legislative branch in other ways. For instance, the framers augmented the powers of the other branches in an attempt to guard against legislative excesses. An energetic executive and an independent judiciary were to be checks on legislative hegemony. The framers also inserted checks external to the legislature, such as the veto power and, at least in Hamilton's view, the power of judicial review, in order to curb legislative excesses. See generally D. Epstein, supra note 19, at 171-79, 185-92 (discussing how "executive energy" and an independent judiciary guard against "unjust and partial laws"). In 
encroachment on the other branches and at the same time protect the public from arbitrary governance. ${ }^{40}$ In other words, as John Jay explained, "It surely does not follow that because they have given the power of making laws to the legislature, that therefore they should likewise give them power to do every other act of sovereignty by which the citizens are to be bound and affected."41

The requirement of bicameralism constrains Congress's power by delimiting how it may act. The Federalist Papers explain that one "remedy . . . is to divide the legislature into different branches; and to render them, by different modes of election and different principles of action, as little connected with each other as the nature of their common functions and their common dependence on the society will admit." 42 Legislative rule could result in the tyranny of the majority or in a legislature captured by faction. ${ }^{43}$ Requiring the concurrence of

addition, the framers adopted a system of enumerated powers, limiting the permissible aims of legislation.

40 Without such barriers, Madison feared that if "the legislature assumes executive and judiciary powers, no opposition is likely to be made; nor, if made, can be effectual; because in that case they may put their proceedings into the form of acts of Assembly." The Federalist No. 48, supra note 21, at 311 (J. Madison). Madison noted that such legislative overreaching had occurred in Virginia and Pennsylvania. Id. at 310-11; see also The Constitution of the Commonwealth of Pennsylvania: To Which is Added a Report of the Committee 35, 37 (1784) (criticizing the Pennsylvania legislature for not conforming to traditional lawmaking procedures). Reiterating these same structural themes in the debates over the Bill of Rights, Madison stated that "the great object" of the proposed amendments was "to limit and qualify the powers of Government, by excepting out of the grant of power those cases in which the Government ought not to act, or to act only in a particular mode." 1 Annals of Cong. 454 (J. Gales ed. 1789).

41 The Federalist No. 64, supra note 21, at 394 (J. Jay). Although Jay was defending the Convention's choice not to give Congress the power to make treaties, his comments are illustrative of the general concern for limiting congressional power to legislation.

42 The Federalist No. 51, supra note 21, at 322 (J. Madison). In the New York Convention, Hamilton defended the tripartite scheme, emphasizing that "[i]n the form of this government, and in the mode of legislation, you find all the checks which the greatest politicians and the best writers have ever conceived." 2 The Debates in the Several State Conventions on the Adoption of the Federal Constitution 348 (J. Elliot rev. ed. 1974) (2d ed. 1836) [hereinafter State Convention Debates] (statement of Hamilton).

${ }^{43}$ See The Federalist No. 10 (J. Madison). The debates over the new constitution clearly reflect the fundamental importance of the bicameralism requirement. James Wilson, for example, observed that "[i]f the Legislative authority be not restrained, there can be neither liberty nor stability, and it can only be restrained by dividing it within itself." 1 Federal Convention Records, supra note 24, at 254; see also id. at 414 (statement of Ellsworth) (The Senate allows "the few to save them from being destroyed by the many.").

Similarly, during the debate in the North Carolina Convention, one participant defended the bicameralism requirement because "[t]he stability of the laws will be greater when the popular 


\section{two distinct houses of Congress}

must be in all cases a salutary check on the government. It doubles the security to the people by requiring the concurrence of two distinct bodies in schemes of usurpation or perfidy ....

... The necessity of a senate is not less indicated by the propensity of all single and numerous assemblies to yield to the impulse of sudden and violent passions, and to be seduced by factious leaders into intemperate and pernicious resolutions. ${ }^{44}$

The requirement of bicameralism also preserves the separation of powers by limiting legislative authority vis-a-vis the other branches. Legislation potentially encroaching upon areas reserved to the other branches can only be passed if both houses concur. ${ }^{45}$ The judiciary and the executive, as well as the public, are therefore shielded to some extent from encroachments by factions. ${ }^{46}$

Similarly, requiring presentment of legislation to the President plainly serves a critical separation of powers function. Hamilton feared that without a veto the legislature could gradually strip the executive of power, either "by successive resolutions" or "by a single vote." 47 According to Hamilton, however, the veto

not only serves as a shield to the executive, but it furnishes an additional security against the enaction of improper laws. It establishes a salutary check upon the legislative body, calculated to guard the community against the effects of faction, precipitancy, or of any impulse unfriendly to the public good, which may happen to influence a majority of that body. ${ }^{48}$

branch, which might be influenced by local views, or the violence of party, is checked by another, whose longer continuance in office will render them more experienced, more temperate, and more competent to decide rightly." 4 State Convention Debates, supra note 42 , at 21 (statement of Davie); see id. at 257 (statement of Pinckney).

44 The Federalist No. 62, supra note 21, at 378-79 (J. Madison); see also 2 J. Story, supra note $25, \S 549$, at 29 (the requirement of bicameralism "forms a great check upon undue, hasty, and oppressive legislation"). Because senators were to be elected indirectly by the state legislatures, and because they were to serve for longer terms than members of the House of Representatives, the Senate could check proposals from the House that were not in the public interest.

45 See G. Wood, supra note 19, at 559.

46 Cf. The Federalist No. 73, supra note 21, at 443 (A. Hamilton) (noting in connection with the executive veto that the greater the number of political actors who must agree on legislation, the greater the safeguards against factions).

47 Id. at 442.

48 Id. at 443 . Hamilton continued that the veto power was necessary given that "a spirit of faction may sometimes pervert [the legislature's] deliberations; that impressions of the moment 
The presentment requirement therefore ensures that the legislative branch will be accountable for its actions. By requiring the procedural step of presentment to the President, the framers circumscribed Congress's ability to pass laws that would encroach on the coordinate branches of government and harm the public at large.

\section{Restraints on the Executive's Mode of Action}

Although many participants in the Convention feared executive power, ${ }^{49}$ the primary architects of the Constitution were more suspicious of the legislative branch. For example, Madison stated that, in contrast to the nearly limitless power of the legislature, "the executive power being restrained within a narrower compass and being more simple in its nature ... projects of usurpation ... would immediately betray and defeat themselves."50 Montesquieu similarly had less fear of executive encroachments because "as the execution has its natural limits, it is useless to confine it; besides, the executive power is generally employed in momentary operations."51 As Justice Story later commented, Congress "must have[ a controlling influence over the executive power, since it holds at its own command all the resources, by which a chief magistrate could make himself formidable. . . . [I]t can unnerve the power of the sword by striking down the arm, which wields it."52

The Constitution does not prescribe procedures comparable to the bicameralism and presentment requirements to constrain the executive. The framers rejected proposals to split the executive, ${ }^{53}$ and the President has never been required to present any planned action to Congress prior to execution.

The lack of procedural restrictions, however, should not be surprising. Because the executive generally implements legislation that already has survived the checks of bicameralism and presentment,

may sometimes hurry it into measures which itself, on maturer reflection, would condemn." Id.

49 See generally E. Corwin, The President: Office and Powers 10-11 (5th ed. 1984) (discussing views of Roger Sherman); Kurland, supra note 8, at 598 (describing dispute over whether executive or legislature posed greater threat to liberty).

50 The Federalist No. 48, supra note 21, at 310 (J. Madison).

51 C. Montesquieu, supra note 6, at 157-58. See generally W. Gwyn, supra note 19, at 100 15 (discussing Montesquieu's conception of separation of powers).

$522 \mathrm{~J}$. Story, supra note $25, \S 530$, at 14 .

53 See The Federalist No. 70 (A. Hamilton); E. Corwin, supra note 49, at 11. 
additional restrictions may have been thought unnecessary. Restraints on the executive branch can therefore be found in the executive's general dependence upon Congress. Except perhaps in the foreign affairs arena, ${ }^{54}$ all commentators concur that the executive has no dispensing power-that is, the executive must abide by statutes as written. ${ }^{55}$ Because executive action is circumscribed by the terms of congressional enactments, Congress may therefore limit presidential powers when it so desires.

The controversy over standing armies at the time of the Convention reflects this understanding of the separation of powers doctrine. In light of the continental experience, many in the new nation vigorously opposed the existence of a standing army and the threat to liberties that it entailed. Hamilton, however, believed that no express prohibition on standing armies was required. He stated that the interests of the people were sufficiently protected by lodging the authority to raise armies in the legislative branch. ${ }^{56}$ Because the executive branch could not act contrary to legislative direction, there was simply no need to fear aggrandizement of executive authority by means of the standing army..$^{57}$

54 Many have argued that, by virtue of his status as Commander in Chief of the Armed Forces, U.S. Const. art. II, $\S 2$, and of his power to receive ambassadors, id. $\S 3$, the President possesses inherent power to at least some degree in the foreign affairs arena. For the purpose of this Article, I have assumed that such a sphere exists, but I have not attempted to delimit its boundaries. For further discussion, see generally E. Corwin, supra note 49, at 208-10 (discussing Hamilton's argument that conduct of foreign affairs is an inherently executive function); C. Crabb \& P. Holt, Invitation to Struggle: Congress, the President and Foreign Policy 18-19 (2d ed. 1984) (deriving executive authority to recognize governments from the express power to receive ambassadors under article II, section 3); L. Henkin, Foreign Affairs and the Constitution 37-65 (1972) (surveying components of the foreign affairs power as historically exercised); Berger, The Presidential Monopoly of Foreign Relations, 71 Mich. L. Rev. 1 (1972) (arguing that executive's assumption of broad and exclusive foreign affairs powers is unconstitutional and dangerous).

55 King James II had asserted the power of dispensing with or suspending laws that he deemed unwise. The Glorious Revolution apparently put an end to such claims. 1 William \& Mary, sess. 2, ch. 2 (1688) ("[T] he pretended power of suspending of laws, or the execution of laws, by regal authority, without consent of parliament, is illegal.").

56 The Federalist No. 24, supra note 21, at 157-58 (A. Hamilton); see Currie, supra note 7, at 25-26.

57 Similarly, the Court has never deviated from its early rulings, based on article I, section 9, that the President cannot expend money to take care that the laws be faithfully executed except pursuant to an appropriation from Congress. The President's authority is confined by the appropriation that Congress sees fit to make. See, e.g., Reeside v. Walker, 52 U.S. (11 How.) 272, 291 (1851). 
What remains controversial is whether the executive has inherent authority to act in the absence of congressional authorization. ${ }^{58}$ Viewed another way, the question is which branch must bear the burden of overcoming inertia: Must the executive persuade Congress to grant authorization, or must Congress act to limit an exercise of executive authority?

The answer to that debate has limited practical importance. ${ }^{59}$ Congress has explicitly vested the President with wide discretion should unforeseen circumstances arise in which executive flexibility is essen-

58 Most commentators have agreed with Professor Corwin's suggestion that at least some realm of inherent authority in domestic matters exists, E. Corwin, supra note 49, at 182-91; see, e.g., Chemerinsky, Controlling Inherent Presidential Power: Providing a Framework for Judicial Review, 56 S. Cal. L. Rev. 863, 866 (1983); Cooper, Comment, 47 Md. L. Rev. 84, 90 (1987); Hirschfield, The Power of the Contemporary Presidency, 14 Parliamentary Affairs 353, 359 (1961); Shane, Presidential Regulatory Oversight and the Separation of Powers: The Constitutionality of Executive Order No. 12291, 23 Ariz. L. Rev. 1235, 1244-45 (1981). President Theodore Roosevelt, under his "stewardship" view of the presidency, insisted that the President had the duty to take any action in the public interest as long as such action did not violate a specific constitutional provision. T. Roosevelt, An Autobiography 371-72 (1914).

Several Supreme Court decisions have suggested that such an inherent authority exists. For example, in In re Neagle, 135 U.S. 1 (1890), the Court upheld the right of the President through the Attorney General to direct a deputy marshal to protect the life of Justice Field, even though no statute specifically authorized such conduct. To reach its conclusion the Court relied on an expansive view of executive power, including any powers "implied by the nature of the government under the Constitution." Id. at 64. Similarly, in In re Debs, 158 U.S. 564, 581-84 (1895), the Court upheld the government's ability to obtain an injunction preventing a threatened railroad strike in Chicago, relying upon a broad notion of inherent executive authority to protect interstate commerce.

59 In my view, however, the absence in the Constitution of any general "procedural" restraints strongly suggests that the executive lacks inherent authority. Executive action would not be "checked" in a constitutional sense unless it flowed from congressional action that conformed to the bicameralism and presentment requirements. Indeed, the idea of "natural limits" on the executive's power would have little force if the executive had a reserve of inherent authority. It is unlikely that the framers intended to place the burden on Congress to overcome inertia and countermand executive actions believed to be against the public interest, see Gewirtz, The Courts, Congress and Executive Policy-Making: Notes on Three Doctrines, Law \& Contemp. Probs., Summer 1976, at 46, 78-79, particularly when a twothirds vote in each house would be needed to override a presidential veto. The balance of power would have sharply tilted towards the executive. Moreover, given that Congress was only infrequently in session, a grant of inherent authority would have afforded the president a significant practical advantage because Congress could not have checked the executive's actions until Congress reconvened. See Brown v. United States, 12 U.S. (8 Cranch) 110 (1814) (rejecting executive's claim of inherent authority to confiscate property held by aliens during War of 1812). 
tial. ${ }^{60}$ Almost every claim of inherent authority can be recast into one of implied statutory authorization. ${ }^{61}$ Irrespective of whether the President can act in the absence of statutory authorization, his actions are therefore directly circumscribed by the terms of the congressional enactments that exist.

Moreover, other checks constrain certain executive actions more directly. For instance, under the appointments clause, ${ }^{62}$ the President cannot appoint any official to a high-ranking position in the executive branch (or the judicial branch) without the approval of the Senate. In effect, the requirement of Senate approval checks the executive branch internally by influencing the choice of individuals who will execute the law. As with the presentment requirement, the need to obtain Senate approval fosters accountability. Hamilton explained that "the necessity of [the Senate's] concurrence would ... . be an excellent check upon a spirit of favoritism in the President, and would tend greatly to prevent the appointment of unfit characters from State prejudice, from family connection, from personal attachment, or from a view to popularity." 63

In addition, the Constitution provides that the President's veto of legislation can be overridden by two-thirds of the members of each house of Congress. The possibility of an override not only forces the President to "present" any planned veto to Congress ${ }^{64}$ but, much like the veto power itself, ensures accountability. At the Convention, Benjamin Franklin warned that, if granted an absolute veto power, the

60 The National Emergencies Act, 50 U.S.C. $\S \S 1601-1651$ (1982 \& Supp. III 1985), is a notable example.

61 For instance, in Dow Chemical Co. v. United States, 476 U.S. 227 (1986), the Supreme Court stated that a congressional decision to vest the executive with investigative authority normally "carries with it all the modes of inquiry and investigation traditionally employed or useful to execute the authority granted," and should therefore be construed broadly. Id. at 233; see also Maul v. United States, 274 U.S. 501, 523-27 (1927) (Brandeis, J., concurring) (finding implied grant of authority to "revenue cutters" to seize American vessels violating navigation laws regardless of distance from coast).

62 U.S. Const. art II, $\S 2$, cl. 2.

63 The Federalist No. 76, supra note 21, at 457 (A. Hamilton); accord 3 J. Story, supra note $25, \S 1525$, at 377 ("The consciousness of this check will make the president more circumspect, and deliberate in his nominations for office."). Indeed, the criticisms leveled at the appointments clause focused not on the impropriety of checking the President's authority but rather on the potential "aristocratic" alliance of the President and the Senate. Blumoff, Separation of Powers and the Origins of the Appointment Clause, 37 Syracuse L. Rev. 1037, 1066-67 (1987).

64 The pocket veto represents only a limited exception. See infra note 188 . 
executive could use that power to "extort money" or force a "private bargain" at the passage of each law. ${ }^{65}$ Hamilton later wrote that "[t]he superior weight and influence of the legislative body in a free government and the hazard to the executive in a trial of strength with that body afford a satisfactory security that the negative would generally be employed with great caution."66 Although permitting Congress to override the President's veto allows Congress to nullify an unpopular exercise of the veto, it also places a check on the President to ensure the responsible exercise of that authority.

\section{Restraints on the Judiciary's Mode of Action}

The framers all seemingly agreed that the judiciary would be the weakest of the three branches. As Hamilton stated, "Whoever attentively considers the different departments of power must perceive that, in a government in which they are separated from each other, the judiciary, from the nature of its functions, will always be the least dangerous to the political rights of the Constitution." 67 Indeed, because it neither commands the purse nor has the power to execute judgments, "incontestably ... the judiciary is beyond comparison the weakest of the three departments of power."68 Despite its apparent "feebleness," the judiciary checks the coordinate branches of government through the power of judicial review. ${ }^{69}$ The grant of life tenure during good behavior ${ }^{70}$ and salary protection ${ }^{71}$ are the principal ways of ensuring that the judiciary is not beholden to the other branches.

651 Federal Convention Records, supra note 24, at 99.

66 The Federalist No. 73, supra note 21, at 444 (A. Hamilton); accord 2 J. Story, supra note $25, \S 883$, at $349-50$ ("[T] here is no practical danger, that this [veto] power would be much, if any, abused by the president.").

67 The Federalist No. 78, supra note 21, at 465 (A. Hamilton).

68 Id. at 465-66. Montesquieu similarly had observed that "[o]f the three powers above mentioned, the judiciary is in some measure next to nothing." See C. Montesquieu, supra note 6 , at 156.

69 The Federalist No. 78, supra note 21, at 466-69 (A. Hamilton). Although the power of judicial review is not explicitly granted in the Constitution, most commentators agree that the "public understanding" was to grant the judiciary such authority. See, e.g., A. Bickel, The Least Dangerous Branch 13-16 (1962).

70 See The Federalist No. 78 (A. Hamilton).

71 See The Federalist No. 79 (A. Hamilton). 
Because the judiciary is therefore insulated from the need to account to the other branches, ${ }^{72}$ the Constitution limits the ways it can act. Just as Congress cannot act without respecting the bicameralism requirement, the judiciary's power for the most part is confined to "cases or controversies" under article III. Judges may pass on the propriety of legislative acts or executive implementation only in a properly constituted judicial case. This requirement provides an internal check on judicial power. ${ }^{73}$ Indeed, Madison "doubted whether it was not going too far to extend the jurisdiction of the Court generally to cases arising Under the Constitution \& whether it ought not to be limited to cases of a Judiciary Nature."74 Other members of the Convention reassured him that "the jurisdiction given was constructively limited to cases of a Judiciary nature."75

Those at the Constitutional Convention specifically rejected a proposed "Council of Revision," which would have allowed the judiciary, along with the President, to "remonstrat[e] ag[ain]st projected encroachments on the people as well as on themselves."76 Madison and James Wilson in particular advocated the council as another method of restraining and overseeing the legislature. ${ }^{77}$ The idea, however, was rejected because it would have afforded the judiciary too much influence on legislation. Elbridge Gerry warned of mixing the executive and the judicial branches, and William Strong explained that "the power of making ought to be kept distinct from that of expounding, the laws. No maxim was better established."78 Luther Martin agreed that such a combination of functions was dangerous, and stated that "as to the Constitutionality of laws, that point will come before the Judges in their proper official character."79 Hamilton

72 Article III judges, of course, like other officers of the United States, may be impeached by Congress. U.S. Const. art. II, § 4.

73 Congress's ability to limit the appellate jurisdiction of the Supreme Court may be a relevant external check. See, e.g., Sager, Foreword: Constitutional Limitations on Congress' Authority to Regulate the Jurisdiction of the Federal Courts, 95 Harv. L. Rev. 17 (1981).

742 Federal Convention Records, supra note 24, at 430.

75 Id.

76 Id. at 73.

77 Id. at 73-74.

78 Id. at 75.

79 Id. at 76. In addition, if judges were vested with nonjudicial responsibility, Martin warned that the people would lose confidence in the impartiality of the judges to the detriment of the entire branch. Id. at 77; see also id. at 79 (statement of Ghorum expressing concern that judges should have "no prepossessions" regarding the laws they are to expound); id. at 80 
later explained that not only might judges

receive an improper bias from having given a previous opinion in their revisionary capacities [but also] by being often associated with the executive, they might be induced to embark too far in the political views of that magistrate, and thus a dangerous combination might by degrees be cemented between the executive and judiciary departments. ${ }^{80}$

In rejecting a role for the judiciary in the proposed Council of Revision, the framers confined the judiciary primarily to one permissible mode of action-that needed to resolve a case or controversy. ${ }^{81}$

In sum, our system of separated powers reflects interests in balance and in accountability. Although the three branches of government are kept largely distinct, the framers did not place much faith in what Madison derisively referred to as a paper demarcation of powers. Instead, through a system of both external and internal checks, they sought to prevent the hegemony of any one branch and, at the same time, sought to prevent control of government by faction. By making the separation of powers scheme self-executing to a certain extent, the constitutional restraints on action serve a more critical purpose than is sometimes understood. Limiting each branch's mode of action is one of the Constitution's principal means of constraining governmental authority. Fidelity to those checks should be enforced as rigorously as any other structural limitation in the Constitution. Insisting upon adherence to those checks and limitations preserves the constitutional system of separated powers to the end of safeguarding individual liberty.

(statement of Rutlidge that "[i]udges ought never to give their opinion on a law till it comes before them").

80 The Federalist No. 73, supra note 21, at 446 (A. Hamilton); see also 2 J. Story, supra note $25, \S 886$, at 352 ("It is impossible to keep the judges too distinct from any other avocation, than that of expounding the laws; and it is peculiarly dangerous to place them in a situation to be either corrupted, or influenced by the executive.").

81 Interestingly, de Tocqueville stressed this limitation as key to the legitimacy and growing authority of the judiciary in the United States. According to de Tocqueville, the judiciary has a "limited [ sphere of action," and "if [a judge] pronounces upon a law without reference to a particular case, he steps right beyond his sphere and invades that of the legislature." A. de Tocqueville, Democracy in America 99-100 (G. Lawrence trans. \& J. Mayer ed. 1969). A judge "never concerns himself with anything except a particular case, and to act he must have cognizance of the matter." Id. at 100. 


\section{Examining Significant Separation of Powers CONTROVERSIES IN LIGHT OF THE CONSTITUTIONAL RESTRAINTS ON MODES OF ACTION}

Although the Supreme Court may not have adopted a coherent approach to separation of powers controversies, its decisions reflect an appropriate solicitude for the constitutional restraints on how the branches may act. In large measure, the Court has struck down legislative, executive, or judicial actions that have seemingly ignored or circumvented those restraints. The Court must only grapple with the more difficult task of balancing the benefits accruing to one branch against the intrusion into the other if it has previously determined that each branch has acted in the constitutionally prescribed way. A balancing approach for all cases is not only unnecessary, but it would also undermine the constitutional imperative of confining each branch to specified means of action.

\section{A. Separation of Powers Conflicts Arising From Congressional Actions}

Courts should scrutinize legislative actions to ensure their conformance with the procedural precepts of the Constitution. Even if the contested legislative measure does not usurp the powers of a coordinate branch of government, the separation of powers doctrine requires invalidating the action if it is procedurally defective.

The relevance of this approach can be seen in evaluating several recent separation of powers controversies. At first glance, the Supreme Court's approach in striking down the legislative measures in INS v. Chadha ${ }^{82}$ and in Bowsher v. Synar ${ }^{83}$ may seem more rigid than its approach in sustaining the congressional measures in Nixon $v$. Administrator of General Services ${ }^{84}$ and in Commodity Futures Trading Commission v. Schor. ${ }^{85}$ This difference, however, principally reflects the presence of an issue in Bowsher and Chadha that is not implicated in the other cases-namely, whether Congress violates the separation of powers doctrine when it binds others without complying with the requirements of bicameralism and presentment.

82462 U.S. 919 (1983).

83478 U.S. 714 (1986).

84433 U.S. 425 (1977).

85478 U.S. 1083 (1986). 


\section{Congressional Actions Through Means Other Than Legislation}

In neither Chadha nor Bowsher would a balancing approach have been appropriate. The question facing the Court did not concern weighing the relative interests of the executive and legislative branches. Indeed, in both cases it is relatively clear that Congress possessed the substantive power to accomplish the legislative aims sought-in Chadha, the power to deport aliens, ${ }^{86}$ and in Bowsher, the power to specify budget cuts. Rather, the question facing the Court on both occasions was whether Congress could accomplish such ends indirectly-through a one-house veto and through a congressional agent, respectively-without complying with the internal checks of bicameralism and presentment.

Although the Court's decision in Chadha invalidating the legislative veto in the Immigration and Nationality $\mathrm{Act}^{87}$ has been subject to much attack, ${ }^{88}$ use of this device cannot easily be reconciled with the constitutional structure of separated powers. As previously discussed, the principal purposes of the separation of powers doctrine are to enhance responsibility to the public interest and to preserve a balance among the branches, ${ }^{89}$ and the specific constitutional prescriptions of bicameralism and presentment are unquestionably designed to those

86 There is some question as to whether Congress's decision to deport individual aliens could be considered a violation of the bill-of-attainder clause. U.S. Const. art I, $\S 9$, cl. 3. Because deportation is not considered "punitive," however, perhaps Congress can directly decide whether to deport a particular alien. See Spann, Deconstructing the Legislative Veto, 68 Minn. L. Rev. 473, 504-05 (1984); Strauss, Was There a Baby in the Bathwater? A Comment on the Supreme Court's Legislative Veto Decision, 1983 Duke L.J. 789, 798. In any event, Congress certainly enjoys the power to make all individuals in Chadha's circumstances deportable and then authorize itself, on a case-by-case basis, to allow individuals to remain in this country.

878 U.S.C. $\S 1254(c)(2)$ (1982).

88 See generally Broyhill \& Starke, Aftershocks of the Loss of the Legislative Veto: Severability and the Need for a Replacement Device, 7 Pace L. Rev. 609 (1987) (arguing that the Chadha decision's focus on procedures is "myopic"); Elliot, INS v. Chadha: The Administrative Constitution, the Constitution, and the Legislative Veto, 1983 Sup. Ct. Rev. 125 (criticizing the majority's formalist focus on procedures); Spann, supra note 86, at 473-74 (arguing that doctrines applied in Chadha were indeterminate, and, therefore, that its result was arbitrary); Strauss, supra note 86 , at $812-17$ (maintaining that legislative veto is unconstitutional in regulatory context, but permissible in political context where it primarily affects relations between Congress and the executive); Tribe, The Legislative Veto Decision: A Law By Any Other Name?, 21 Harv. J. Legis. 1 (1984) (denying that exercise of veto in Chadha was legislative action and questioning principle that Congress cannot delegate power to itself).

89 See supra notes $20-81$ and accompanying text. 
ends. Both requirements guard against precipitous legislative actions and the rule of faction. To sanction congressional actions that violate those safeguards would undermine the protections afforded by the Constitution to coordinate branches of government as well as to individuals.

Chadha is illustrative. Under the Immigration and Nationality Act, Congress vested the United States Attorney General with the discretion to suspend deportation and grant permanent residence status to certain excludable aliens. ${ }^{90}$ After reviewing the relevant evidence, an immigration judge, on behalf of the Attorney General, determined that Chadha met the requirements under the Act and should be granted permanent residence status. Pursuant to the Act's legislative veto provisions, the Attorney General communicated that determination to Congress. Either house could then have passed, within the next two sessions, a resolution "vetoing" the Attorney General's findings and causing Chadha to be deported. ${ }^{91}$

On December 12, 1975, seven days before the end of the last session in which Congress could so act, the Chairman of the Judiciary Subcommittee on Immigration, Citizenship, and International Law introduced a resolution against granting permanent residence status to six particular aliens, including Chadha. The resolution was reported to the Judiciary Committee and then to the House of Representatives for a vote, evidently without any further discussion..$^{92}$ On the floor of the House, the Chairman of the Subcommittee stated that "[i]t was the feeling of the committee, after reviewing 340 cases, that the aliens contained in the resolution [including Chadha] did not meet these statutory requirements, particularly as it relates to hardship; and it is the opinion of the committee that their deportation should not be suspended."93 The House then passed the resolution without further debate and without a recorded vote. ${ }^{94}$

Exercise of the legislative veto therefore allowed one house of Congress to determine the rights of an individual, Chadha, without being fully accountable for its actions. The House did not face the necessity

\footnotetext{
90 See 8 U.S.C. $\S 1254(a)$.

91 See id. $\S 1254(\mathrm{c})(2)$.

92 Chadha, 462 U.S. at 926-27.

93 Id. at 926 (quoting 121 Cong. Rec. 40,800 (1975) (statement of Rep. Eilberg)).

94 Id. at 927.
} 
of obtaining the agreement of both the Senate and the President. Its action was therefore "unchecked" in a constitutional sense.

Despite its seeming logic, Chadha has been widely criticized, primarily on three grounds: first, because the veto is not "legislation" subject to the bicameralism and presentment requirements; 95 second, because Congress did not alter the rights of Chadha as it only afforded him a conditional right in the first place; ${ }^{96}$ and third, because the veto is an indispensable mechanism for Congress to control broad delegations to the executive branch. ${ }^{97}$ All three criticisms fail because they misconstrue the structure of separated powers under the Constitution.

Commentators agree that Congress must respect the bicameralism and presentment requirements when passing a law. Those who have criticized the ruling in Chadha, however, argue that there is no reason to apply such requirements to exercise of a veto.

The response to that argument is clear: the constitutional system of checks and balances circumscribes the ways each branch may act before binding those outside its branch. The bicameralism and presentment requirements do not merely shape the content of particular pieces of legislation; they also play a pivotal role in maintaining the constitutional scheme by limiting the power of the legislative branch. ${ }^{98}$ The logic of the system of restraints on action requires that any legislative action binding on individuals or coordinate branches of government must be taken in conformance with those constraints.

Congress may, of course, act in many ways that affect those outside its branch. It conducts oversight hearings, passes hortatory resolutions, and issues reports on subjects that unquestionably have a profound effect on many individuals, as well as on the coordinate branches of government. When those acts have the binding force of law, however, the internal checks circumscribing congressional authority must be respected. ${ }^{99}$ Because exercise of a veto unquestion-

95 See Elliot, supra note 88, at 131-44; Strauss, supra note 86 , at 798.

96 See Elliot, supra note 88, at 134-37; Strauss, supra note 86, at 796.

97 See Broyhill \& Starke, supra note 88, at 610-19.

98 See supra notes $33-48$ and accompanying text.

99 One principal exception exists that by no means swallows the general rule. Congress may act in other than the constitutionally prescribed manner when it exercises an inherent authority. Congress has long been held, for instance, to possess the contempt power, see Anderson v. Dunn, 19 U.S. (6 Wheat) 204 (1821), and congressional committees may issue subpoenas to individuals or government agencies to solicit testimony or other information. Those powers have been viewed as inherent in Congress because otherwise Congress would be 
ably is binding, ${ }^{100}$ a veto falls squarely within the type of legislative action that can only be taken by both houses of Congress after presentment to the President. ${ }^{101}$

powerless to investigate and fulfill its constitutional responsibilities. Id. at 228-29; cf. McGrain v. Daugherty, 273 U.S. 135, 174 (1927) (powers to investigate and to compel cooperation inherent in Congress).

Congress similarly need not comply with the presentment and bicameralism requirements when it binds only those within its branch. Article I, section 5 authorizes each house to make its own procedural rules and discipline its own members. See Powell v. McCormack, 395 U.S. 486, 521-48 (1969) (recognizing Congress's role in disciplining its own members). Congress can also appoint its own officers and provide suitable direction without conforming to the article I procedures for lawmaking. See Chadha, 462 U.S. at 956 n.21. Congressional actions binding only on Congress do not directly threaten the powers of the coordinate branches of government or the rights of individuals outside of the legislative branch.

The judiciary similarly can act in other than the constitutionally prescribed manner through the contempt power, by issuing subpoenas, or when its acts bind only those in the judicial branch. See infra notes $213,226,229$. The executive's ability through executive orders to bind those within that branch might be considered an analogous inherent power. See infra note 179.

In any event, the justification for such exceptional exercises of power cannot be extended to the veto. No one would suggest that the veto power is inherent in Congress, and everyone would agree that its exercise binds those outside of Congress.

100 Not all exercises of the legislative veto bind individuals such as Chadha. For instance, veto of a proposed agency regulation only requires the agency to reformulate policy. Nonetheless, the veto is binding on the executive branch, preventing the agency's selected policy from having the force of law.

In any event, exercise of a veto, particularly if it rejects some agency rules but not others, closely resembles legislation. In both contexts, Congress is making policy judgments to shape future conduct. Cloaking such policy judgments in the garb of a veto not only undermines accountability, but it also shields the policy judgment from judicial review, a fundamental external check on the legislature's power. This potential lack of review highlights the importance of Congress's adhering to the article I procedures for binding those outside its branch.

In 1897, the Senate Judiciary Committee reached the same conclusion. S. Rep. No. 1335, 54th Cong., 2d Sess. 8 (1897) (concluding that presentment to the President is necessary in the case of all resolutions that "contain matter which is properly regarded as legislative in its character and effect"); see also 6 Op. Att'y Gen. 680, 684 (1854) ("[T]he Constitution has not given to either branch of the legislature the power, by separate resolution of its own . . . to apply [a general law] executively to a given case.").

101 Indeed, even though the veto may not reflect any positive policy, the framers believed that the President was participating in lawmaking when he exercised his veto powers. See generally The Federalist No. 73, supra note 21, at 443-46 (A. Hamilton) (describing how the executive veto will improve the lawmaking process).

In addition, the presentment requirement applies not only to "bills," but also to "[e]very Order, Resolution, or Vote to which the Concurrence of the Senate and House of Representatives may be necessary." U.S. Const. art. I, § 7, cl. 3. Although not dispositive, the text itself suggests that the framers did not intend Congress to be able to make policy except through these procedures. See 2 Federal Convention Records, supra note 24, at 301 
Indeed, exercise of the legislative veto undercuts the legislative accountability that the framers sought to achieve. Individual members of a particular house in Congress are not constrained when exercising a veto by the need to persuade members of the other house and the President of the correctness of their decision. Moreover, interest groups can gain more influence in congressional deliberations because of their ability to lobby effectively at the subcommittee level. ${ }^{102}$ Many opposed the veto precisely because it afforded affluent lobbies or interest groups such an advantage. ${ }^{103}$ The constitutional interest in making Congress accountable for its actions therefore supports applying the bicameralism and presentment requirements to exercise of the veto.

The second argument leveled against Chadha maintains that exercise of the veto does not affect the rights of any individual or the powers of either coordinate branch. Under that view, Congress granted a conditional right to Chadha that would have "ripened" only if neither house of Congress disagreed with the Attorney General. That argument has an element of sophistry to it because the policy to which both houses of Congress and the President agreed in the initial piece of legislation is not the same policy that is reflected in exercise of the legislative veto. Even if Congress as a whole only vested in Chadha a conditional right to remain in this country, one house of Congress plainly made the ultimate decision concerning his legal status. If Congress could create conditional rights and vest one of its committees with the power to determine whether those rights should be recognized, then it could retain a veto over every executive branch decision on the ground that it had only conditionally author-

(statement of Madison) ("II]f the negative of the President was confined to bills; it would be evaded by acts under the form and name of Resolutions, votes, .....").

102 Bruff \& Gellhorn, Congressional Control of Administrative Regulation: A Study of Legislative Vetoes, 90 Harv. L. Rev. 1369, 1378-82, 1417-20 (1977). Bruff and Gellhorn also determined that threatened use of the legislative veto affords congressional committees a powerful tool to influence executive branch action. Agencies may have changed proposed rules or courses of action not only because of the fear of a veto, but also because of the threatened delay. Id. at 1385.

103 See Martin, supra note 12, at 272-80; Scalia, supra note 12, at 24-25. Although congressional subcommittees-as well as interest groups-may still exercise great influence in enacting a wide variety of legislative measures, all such measures must at least receive the formal sanction of both houses of Congress and must be presented to the President. 
ized the executive to enforce the laws or make expenditures. ${ }^{104}$ When it is seen that the decisions whether to use a veto and how much of an executive action to veto constitute policymaking, this criticism of Chadha falls apart.

Third, some argue that the legislative veto is a necessary invention to aid Congress in controlling its broad delegations to administrative agencies. In other words, many implicitly suggest that the veto should be upheld because it is a politically useful device. In nearly every case, Congress may have weighty interests in using a legislative veto or other control mechanism. Any balancing approach would most likely favor the legislative branch because such interests are more palpable than the possible intrusion into the coordinate branch's affairs.

But if the Constitution requires bicameralism and presentment in order to promote congressional accountability to the other branches and to the public interest, then use of a balancing test would simply circumvent the constitutional scheme. Congress through its exercise of article I powers cannot swallow other constitutional provisions, such as the appointments clause, ${ }^{105}$ the compensation clause in article III, ${ }^{106}$ or the presentment clause. The Court should therefore reject any congressional action binding on those outside Congress unless it is taken in accordance with the requirements of presentment and bicameralism. "[T] $]$ he fact that a given law or procedure is efficient, convenient, and useful in facilitating functions of government, standing alone, will not save it if it is contrary to the Constitution. Convenience and efficiency are not the primary objectives-or the hallmarks-of democratic government . . .."107 Thus, any congressional action that violates an "internal" constitutional check should

104 Although Congress may fashion a wide variety of rights conditioned on acts of those outside of government, see, e.g., Currin v. Wallace, 306 U.S. 1 (1939), it may not, in light of the constitutional requirements of bicameralism and presentment, delegate to one of its committees or agents the power to determine such conditions. See Martin, supra note 12, at 296-300. Congress's ability to delegate functions to those outside government is in any event limited by the appointments clause, which the Supreme Court has construed to apply to any individual exercising "significant" authority under the laws of the United States. See Buckley v. Valeo, 424 U.S. 1, 126 (1976).

105 See Buckley, 424 U.S. at 127.

106 See United States v. Will, 449 U.S. 200, 226 (1980).

107 Chadha, 462 U.S. at 944. 
be invalidated without examination of the congressional interests at stake.

The Court's analysis in Bowsher directly follows from that in Chadha, at least when it is determined that the Comptroller General is an officer of the legislative branch. ${ }^{108}$ Under the Gramm-RudmanHollings Act, ${ }^{109}$ Congress authorized the Comptroller General, based upon economic forecasts proposed by the Office of Management and Budget (OMB) and the Congressional Budget Office (CBO), to specify the spending reductions necessary to keep the budget deficit within the limits set by Congress. The Act provided that the Comptroller General was to use independent judgment in making the determination, showing "due regard" for the OMB-CBO forecasts. ${ }^{10}$ The Act directed the President then to issue a sequestration order "provid[ing] for reductions in [a] manner . . . consistent with [the Comptroller General's] report in all respects."111 If Congress can bind those outside its branch only if it has adhered to the specific constitutional prescriptions governing how it must act, then it surely cannot circumvent those restrictions by vesting the power to bind others in an agent whom it controls.

The majority adopted the substance of that analysis even though it focused on the flipside of the Chadha problem-Congress's attempt through its agent to implement the law. The Court held that "Con-

108 The majority determined that the Comptroller General was an officer of the legislative branch because Congress made the Comptroller General removable at the initiative of Congress for any one of several causes. Bowsher, 478 U.S. at 727-32. The majority concluded that "[i]n constitutional terms, the removal powers over the Comptroller General's office dictate that he will be subservient to Congress." Id. at 730. Although the removal provisions may be an important indication of the officer's status, they should not be dispositive in and of themselves. If the mere fact of removability by Congress ensures that an officer is part of the legislative branch, then the directors of the Tennessee Valley Authority must be considered to be legislative officers. See 16 U.S.C. $\$ 831 c(f)$ (1982) ("[A]ny member of [the TVA] may be removed from office at any time by a concurrent resolution of the Senate and the House of Representatives."). Their functions and allegiances, however, plainly ally them with the executive branch, and at least one court has upheld the President's plenary exercise of the power to remove them. See Morgan v. TVA, 115 F.2d 990 (6th Cir. 1940), cert. denied, 312 U.S. 701 (1941).

In contrast, Justice Stevens in concurrence agreed that the Comptroller General is an officer of Congress, but only because an examination of the historical relationship between Congress and the Comptroller General, as well as of the web of statutory provisions that define his functions, demonstrates such status. Bowsher, 478 U.S. at 741-46.

1092 U.S.C. $\S \S 901-907$ (Supp. IV 1986).

110 Id. $\S 901(b)(1)$.

111 Id. $\S 902(a)(3)$. 
gress cannot reserve for itself the power of removal of an officer charged with the execution of the laws." 112 Within "execution of the laws," it included the Comptroller General's administrative duties under the Gramm-Rudman-Hollings Act, because those duties involved determining "precisely what budgetary calculations are required." 113 The majority made it clear that "once Congress makes its choice in enacting legislation, its participation [and those of its agents] ends. Congress can thereafter control the execution of its enactments only indirectly-by passing new legislation."114 Viewed another way, "[t]he structure of the Constitution does not permit Congress to execute the laws; it follows that Congress cannot grant to an officer under its control what it does not possess." 115

Justice Stevens, in a concurrence joined by Justice Marshall, more explicitly relied on the analysis in Chadha. He observed that

Article I of the Constitution specifies the procedures that Congress must follow when it makes policy that binds the Nation .... If Congress were free to delegate its policymaking authority to one of its components, or to one of its agents, it would be able to evade "the carefully crafted restraints spelled out in the Constitution."

To Justice Stevens, therefore, "the critical inquiry . . concerns . . . the manner in which Congress and its agents may act." 117 No balancing is permitted if Congress acts outside the procedural requirements specified in the Constitution. ${ }^{118}$

112 Bowsher, 478 U.S. at 726 (citing Chadha, 462 U.S. at 958). But see Banks \& Straussman, supra note 8, at 673-82 (arguing that Bowsher, even after Chadha, is indefensible).

113 Bowsher, 478 U.S. at 733.

114 Id. at 733-34 (citing Chadha, 462 U.S. at 958).

115 Id. at 726.

116 Id. at 754-55 (quoting Chadha, 462 U.S. at 959).

117 Id. at 758.

118 Justice White dissented, decrying "the Court's willingness to interpose its distressingly formalistic view of separation of powers as a bar to the attainment of government objectives through the means chosen by the Congress and the President in the legislative process established by the Constitution." Id. at 759. In particular, he disagreed with the plurality and the majority's conclusion that the Comptroller General was an officer of Congress. Id. at 76667. Justice Blackmun, in a separate dissent, agreed with Justice White on that point, and also argued that Congress can vest its officers with administrative authority as long as it does not exercise close control over its officer's functions. Id. at $778 \mathrm{n} .1$; cf. Banks \& Straussman, supra note 8, at 677-79 (criticizing the majority's finding that the Comptroller General's exercise of administrative authority is problematic under the separation of powers doctrine). 
Courts should therefore scrutinize with great care any legislative scheme in which Congress as a whole has authorized one of its agents or constituent parts to bind those outside of Congress. ${ }^{119}$ Such measures differ critically from congressional delegations of authority to administrative agencies or to tribunals not located in the legislative branch. To be sure, Congress's initial decision to delegate authority to agents of either the executive or of itself conforms to the internal checks prescribed in the Constitution. But when Congress delegates authority to its own agent, as in Bowsher (or to one of its constituent parts as in Chadha), then the congressional agent's actions supplement the original piece of legislation without complying with the article I procedures for lawmaking. Agents of the executive branch (including so-called "independent" agencies), needless to say, are not comparably bound by the article I restrictions, in part because of the framers' greater fear of unchecked legislative power. ${ }^{120}$

Moreover, there is a natural check against congressional delegation of authority to administrative agencies that does not protect against Congress's decision to delegate authority to one of its constituent parts or agents: Congress must be willing to part with that power. Acts taken pursuant to delegations of authority to the executive branch therefore have the imprimatur of both Congress and the executive, and the judiciary customarily polices that accord by reviewing administrative acts for consistency with the congressional mandate. Acts taken directly by agents of Congress, however, do not require the concurrence of the executive branch, may not be subject to judicial review, and do not reflect the concern for accountability underly-

119 Congressional efforts to retain a role in the removal of executive branch officials should similarly be invalidated without consideration of the legislative interests at stake. Although certainly inconsistent in tone, the Supreme Court's decisions in Myers v. United States, 272 U.S. 52 (1926) (invalidating statute providing that certain postmasters could only be removed with the consent of the Senate) and Humphrey's Executor v. United States, 295 U.S. 602 (1935) (upholding statutory limitation on President's ability to remove FTC Commissioner) can largely be reconciled on that basis. When Congress reserves for itself a part in supervising or removing executive officers, as in Myers, no balancing is required because Congress has breached the constitutional restraints on its action. On the other hand, when Congress, in the exercise of its Article I responsibilities, affords an executive officer a measure of statutory tenure, as in Humphrey's Executor, then some type of balancing is required to determine whether Congress's enactment unduly interferes with the executive's responsibility to "take care" that the laws are faithfully enforced.

120 See supra text accompanying notes 49-55. 
ing the separation of powers scheme. ${ }^{121}$ Thus, although Congress's initial action in delegating authority is the same in both contexts, it is the second congressional action that is telling. It is therefore not surprising that the Supreme Court has used more exacting scrutiny in reviewing legislative delegations to agents of Congress than to agents of the other branches.

\section{Unavoidable Conflict Between Congress and its Coordinate Branches}

In contrast to the statutes at issue in Chadha and Bowsher, legislative measures that conform to the bicameralism and presentment requirements should be assessed more flexibly. Courts must accommodate the congressional aims furthered by such enactments with the perceived incursion into the independence or powers of a coordinate branch. ${ }^{122}$ A functionalist approach is therefore needed to resolve such controversies. Although the Court has not agreed on the applicable test, the issues addressed in such cases generally include whether the contested action usurps a function constitutionally reserved to the other branch ${ }^{123}$ or whether it threatens to interfere substantially with operations of the other branch of government.

The question presented in Nixon v. Administrator of General Services, ${ }^{124}$ for example, was whether Congress, through title I of the Presidential Recordings and Materials Preservation Act, ${ }^{125}$ unduly impinged upon the prerogatives of the President by asserting limited control over presidential papers. Although the Act did not provide any direct role for Congress, it directed executive branch archivists to screen all presidential papers and to determine which papers should

121 But see Tribe, supra note 88, at 9-18 (arguing that the two types of delegation are functionally indistinguishable).

122 Some enactments, such as the War Powers Resolution, 50 U.S.C. $\S \S 1541-1548$ (1982), are probably not justiciable under the political question doctrine. See, e.g., Massachusetts v. Laird, 400 U.S. 886 (1970) (holding nonjusticiable Massachusetts' challenge to legitimacy of Vietnam War); Sanchez-Espinoza v. Reagan, 770 F.2d 202 (D.C. Cir. 1985) (challenge to government aid to Nicaraguan insurgents found nonjusticiable); Crockett v. Reagan, 720 F.2d 1355 (D.C. Cir. 1983) (challenge to government aid to El Salvador found nonjusticiable), cert. denied, 467 U.S. 1251 (1984).

123 For instance, in Buckley v. Valeo, 424 U.S. 1, 127 (1970), the Supreme Court concluded that Congress directly assumed the President's appointment authority by appointing several members of the Federal Election Commission.

124433 U.S. 425 (1977).

125 Pub. L. No. 93-526, 88 Stat. 1695, reprinted in 44 U.S.C. $\$ 2111$ note (1982). 
be considered public and which private. Congress specified seven factors to be considered by the archivists in reaching that determination. The archivists were then to fashion a system to grant eventual access to those papers deemed public. In challenging the enactment, former President Nixon argued in part that releasing such information to the public would chill the candor of both the President and his advisers. ${ }^{126}$

To assess the competing claims, the Court stated that

in determining the proper balance between the coordinate branches, the proper inquiry focuses on the extent to which [the contested law] prevents the Executive Branch from accomplishing its constitutionally assigned functions. Only where the potential for disruption is present must we then determine whether that impact is justified by an overriding need to promote objectives within the constitutional authority of Congress. ${ }^{127}$

In essence, the Court articulated a two-part test: first, whether the potential for disruption is present; and second, whether any potential disruption can be justified by Congress's overriding need for the legislation.

The Court's application of that test, however, was not as clear. Principally because the Act vested control of the screening process in an officer of the executive branch, the Administrator of the General Services Administration, the Court concluded that there was no realistic threat to disruption of the executive branch. ${ }^{128}$ The Court, therefore, may not have ever reached the second part of its test. Some doubt remains because the majority also stated that operation of the Act potentially would result in a "limited intrusion" into presidential independence because of the threat to confidentiality of presidential communications. ${ }^{129}$ Instead of determining that no potential for disruption existed, the Court may have therefore concluded that the congressional objective of providing public access overrode the limited threat of intrusion into the executive branch's operations. ${ }^{130}$

126 Nixon, 433 U.S. at $440-41$.

127 Id. at 443.

128 Id. at $443-46$.

129 Id. at 451.

130 In dissent, Justice Rehnquist quarrelled with both the majority's articulation and application of the relevant test. In his view, by restraining candid discourse to and from the President, the Act substantially infringed upon the executive's ability to manage the executive 
The Court could not have decided the case without engaging in some form of balancing. By its very nature, a claim of executive privilege requires weighing the strength of the executive interest in confidentiality against the legislative (or judicial) interest in obtaining access to the material. If Congress had vested in one of its committees the power to determine which presidential papers to release, the case would have presented a different question, which the Court could have resolved without engaging in a balancing test. Because Congress's action in Nixon conformed to the procedural requirements in the Constitution, however, balancing was inevitable.

An analogous approach to separation of powers issues can be seen in the recent Supreme Court decision in Commodity Futures Trading Commission v. Schor. ${ }^{131}$ The question raised in Schor was whether the Commodity Futures Trading Commission (CFTC)—an agency within the executive branch-could adjudicate in reparation proceedings counterclaims arising under state law. ${ }^{132}$ Under section 74 of the Commodity Exchange Act, Congress vested customers of commodity brokers with the right to bring before the Commission reparation claims against their brokers for alleged violations of the Act or Commission regulations. ${ }^{133}$ Such claims typically allege improper execution of market orders or manipulation of the commodities market. Through the reparations procedure, Congress intended to provide an inexpensive and yet expeditious forum for such claims. ${ }^{134}$

In addition to the customers' claims, the Commission, by regulation (with Congress's implicit sanction), ${ }^{135}$ authorized the brokers to

branch and to "take care" that the laws be faithfully executed. Id. at 546-58. Moreover, in contrast to the majority's apparent dictum, Justice Rehnquist stated that a "significant" intrusion could not be justified by the importance of the legislative aims. Any balancing test ultimately would distort the constitutional framework. Id. at 558-60.

Chief Justice Burger also dissented, specifically taking issue with the vague balancing or "disruption" standard articulated by the Court. Id. at 512-13.

131478 U.S. 833 (1986).

132 None of the parties challenged the Commission's jurisdiction over claims arising under the Commodities Exchange Act, ch. 545, §§ 1-13, 49 Stat. 1491 (codified as amended in scattered sections of 7 U.S.C.).

133 Schor, 478 U.S. at 836 (citing 7 U.S.C. $§ 18$ (1982)).

134 Id.

135 Id. at 841-42. In light of the constitutional question presented, the United States Court of Appeals for the District of Columbia Circuit construed the statutory authorization narrowly to preclude the CFTC from entertaining counterclaim jurisdiction. Schor v. CFTC, 740 F.2d 1262, 1264 (D.C. Cir. 1984), vacated, 473 U.S. 922, judgment reinstated on remand, 770 F.2d 211 (D.C. Cir. 1985), rev'd, 478 U.S. 833 (1986). 
raise in the reparation proceedings any counterclaim arising out of the same events set forth in the customers' complaints. By authorizing counterclaims, the Commission wished to ensure the efficacy of the reparations scheme. If the Commission did not have such jurisdiction, a party wishing to assert a counterclaim would be forced either to litigate the same disputed issues in two different fora or to forgo any recourse to the Commission.

In Schor, the customer argued that the broker could not raise its common law counterclaim before the Commission. Consequently, this challenge to the Act, like the challenge to the Bankruptcy Act of 1978 several years earlier in Northern Pipeline Construction Co. v. Marathon Oil Pipe Line Co. ${ }^{136}$ rested on the potential dilution of federal judicial power resulting from the adjudication of common law claims by administrative tribunals.

In framing the separation of powers issue, the Court stated,

In reviewing Article III challenges, we have weighed a number of factors, none of which has been deemed determinative, with an eye to the practical effect that the congressional action will have on the constitutionally assigned role of the federal judiciary. Among the factors upon which we have focused are the extent to which the "essential attributes of judicial power" are reserved to Article III courts, ... the origins and importance of the right to be adjudicated, and the concerns that drove Congress to depart from the requirements of Article III. ${ }^{137}$

136458 U.S. 50 (1982) (invalidating the jurisdictional provisions of the Bankruptcy Act of 1978, 28 U.S.C. § 1471 (Supp. IV 1976)). In Northern Pipeline, the plurality concluded that vesting bankruptcy judges with the power to hear nonfederal causes of action only peripherally related to core bankruptcy issues intruded into the independence of the article III judiciary: "The potential for encroachment upon powers reserved to the Judicial Branch through the device of 'specialized' legislative courts is dramatically evidenced in the jurisdiction granted to the courts created by the Act before us." Id. at 74. Although its analysis was not entirely coherent, the plurality believed that judicial independence was threatened by congressional efforts to strip courts of the "essential attributes of judicial authority"-in this case the power to hear common law claims. Id. at 87. Presumably, the plurality feared that an article III judiciary, shorn of its traditional functions, would too easily defer to Congress's will in the cases that remained.

In any event, the plurality stated that once a court finds the potential for intrusion, it can uphold Congress's grant of jurisdiction only if Congress is exercising an exceptional grant of power, such as where Congress exercises its authority regarding territorial courts. Id. at 70-71.

137 Schor, 478 U.S. at 851 (citation omitted). 
Thus, the Court adhered to the approach of Nixon and assessed the intrusion in a pragmatic manner by balancing the congressional objective against the impact on the coordinate branch of government. The Court ultimately concluded that "the congressional authorization of limited CFTC jurisdiction over a narrow class of common law claims as an incident to the CFTC's primary, and unchallenged, adjudicative function does not create a substantial threat to the separation of powers." 138

As in Nixon, the Court could not have resolved the dispute in Schor without weighing the respective interests of both the legislature and the judiciary regarding the administrative scheme. The wide disagreements among the justices in both cases amply illustrate the discretion inherent in any balancing approach. Yet because Congress adhered to the proper procedures in enacting the reparations scheme and did not retain any role in the adjudicative process, some pragmatic balancing was unavoidable. ${ }^{139}$

\section{Reconciling Bowsher and Schor}

To be sure, the justices apparently were hard pressed to reconcile the approaches taken in Bowsher and in Schor. In Schor, for instance,

138 Id. at 854 (citation omitted). Much like Justice Rehnquist in Nixon, Justice Brennan dissented, disagreeing with the majority's premise that no significant intrusion was present. Each congressional decision to remove cases from the article III judiciary and to place them before an alternative tribunal threatens not only the impartial adjudication of such cases, but also the integrity of the article III judiciary. Indeed, because in his view vesting counterclaim jurisdiction in the Commission threatened judicial independence, Justice Brennan believed that no balancing was appropriate: "The danger of the Court's balancing approach is, of course, that as individual cases accumulate in which the Court finds that the short-term benefits of efficiency outweigh the long-term benefits of judicial independence, the protections of Article III will be eviscerated." Id. at 863-64.

139 These two cases perhaps can best be understood as holding that where Congress permits the coordinate branch to retain autonomy-in Nixon because the screening was to be performed by members of the executive branch, and in Schor because judicial review was available and only the article III judiciary could enforce Commission orders-no substantial separation of powers problem exists. See also United States v. Raddatz, 447 U.S. 667, 685 (1980) (Blackmun, J., concurring) (noting that the "only conceivable danger of a 'threat' to the 'independence' of the magistrates comes from within, rather than without, the judicial department"); Geras v. Lafayette Display Fixtures, Inc., 742 F.2d 1037, 1043 (7th Cir. 1984) (Reference of suit to magistrates with parties' consent was permitted because the magistrates' dependence on the article III judiciary "does not implicate either the judiciary's or the magistrates' independence vis a vis the Executive or Legislative Branches. ... In other words, 'subordinate adjuncts,' by reason of their close dependence on independent judicial officers, are shielded against influence from the political branches of government."). 
Justice O'Connor distinguished Bowsher on the ground that Schor "raises no question of the aggrandizement of congressional power at the expense of a coordinate branch. Instead, the separation of powers question presented in this case is whether Congress impermissibly undermined, without appreciable expansion of its own power, the role of the Judicial Branch." 140 Although that description may be correct, it is unclear why inquiring whether Congress expanded its own power is relevant. ${ }^{141}$ The balance of powers among the branches will be altered irrespective of whether Congress directly adds to its own authority because Congress's power vis-a-vis the other branch will have increased in either instance. ${ }^{142}$

Justice O'Connor also explained that "[i]n any case, we have, consistent with Bowsher, looked to a number of factors in evaluating the extent to which the congressional scheme endangers separation of powers principles under the circumstances presented."143 That statement, however, in no way describes Bowsher unless Bowsher is to be recast as reflecting some type of balance between the potential incursion into the President's ability to manage the executive branch and the legislative aims underlying enactment of the budget measure. Although the executive branch had argued that the intrusion was

140 Schor, 478 U.S. at 856-57.

141 Justice O'Connor's attempted reconciliation does not even work well in Bowsher because in that case there was little fear of congressional increase in power. Indeed, Congress could have made spending cuts directly so that the issue of congressional aggrandizement of authority appears marginal at best.

Viewed another way, if " $L$ " represents the power of the legislative branch; " $J$," the power of the judicial branch; and " $E$," that of the executive branch, Congress's proportional share of the federal government's power can be expressed algebraically as $L /(L+E+J)$. In the first type of case addressed by Justice $O$ 'Connor, when Congress aggrandizes its own authority by usurping the functions by the amount " $Y$ " of a coordinate branch (for purposes of illustration only, the judiciary), Congress's increased power can be represented as $(L+Y) /(L+Y+E+J-Y)$ or $(L+Y) /(L+E+J)$. In the second type, when Congress takes power away from the judiciary without directly increasing its own power, its share of power then can be expressed as $L /$ $(L+E+J-X)$, where " $X$ " is the amount by which the judiciary's power was reduced. Although the separation of powers threat may often be less in the second situation, whenever $Y<L X /(L+E+J-X)$, the shift in the allocation of powers will be greater in the second type than in the first. Using a different approach to resolve separation of powers questions merely because of direct congressional aggrandizement therefore seems unfounded.

142 If, by "aggrandizement of congressional power at the expense of a coordinate branch," Justice O'Connor meant to describe a situation in which Congress legislated for itself a role in the other branch's functions, and not merely augmented its power through legislation, then the distinction drawn in Schor parallels the thesis presented in this Article.

143 Schor, 478 U.S. at 857. 
great because only an officer removable at the will of the President could perform such budgetary functions, the Court in Bowsher explicitly declined to rely on that argument. ${ }^{144}$

Justice Brennan, dissenting in Schor, understandably did not accept Justice O'Connor's efforts to reconcile the cases:

It is impossible to reconcile the radically different approaches the Court takes to separation of powers in this case and in Bowsher. The Framers established three coequal branches of government and intended to preserve each from encroachment by either of the others. The Constitution did not grant Congress the general authority to bypass the judiciary whenever Congress deems it advisable, any more than it granted Congress the authority to arrogate to itself executive functions. ${ }^{145}$

Viewed within the framework of the internal checks prescribed in the Constitution, however, the relationship between Bowsher and Schor becomes apparent. Congress can only bind those outside its branch pursuant to the lawmaking procedures prescribed in the Constitution. ${ }^{146}$

This analysis of Chadha and Bowsher also proves instructive in understanding Ameron, Inc. v. United States Army Corps of Engineers. ${ }^{147}$ Under the Competition in Contracting Act of $1984,{ }^{148}$ when an unsuccessful bidder on a government contract files a timely protest with the Comptroller General, the contracting agency may not award the contract and must suspend performance if the contract has already been awarded, pending a nonbinding decision on the protest by the Comptroller General. As soon as the Comptroller General issues his decision, which is normally within ninety working days, ${ }^{149}$ the stay is automatically lifted. Although the Comptroller General's

144 See Bowsher, 478 U.S. at 725 n.4; id. at 760-61 (White, J., dissenting).

145 Schor, 478 U.S. at 865.

146 Justice Stevens analogized this requirement to a "due process of lawmaking." Bowsher, 478 U.S. at 757 n.23; see also Linde, Due Process of Lawmaking, 55 Neb. L. Rev. 195 (1970) (arguing that the due process clause should safeguard legislative process, rather than limit substantive means and ends of legislation). Justice Stevens's characterization is consistent with the concerns for accountability and balance underlying the constitutional scheme of separation of powers.

147809 F.2d 979 (3d Cir. 1986), cert. granted, 108 S. Ct. 1218 (1988).

148 Pub. L. No. 98-369, 98 Stat. 1175 (codified in scattered sections of 5, 7, 12, 16, 26, 28, 29, 31, 41, 42, 46 U.S.C.).

14931 U.S.C. $\S 3554(a)(1)$ (Supp. IV 1986). 
decision is in no way binding, he can award the prevailing protester attorney's fees and the costs of preparing its bid and proposal. ${ }^{150}$

The Comptroller General may also shorten or lengthen the stay period in several circumstances. If he "determines and states in writing the reasons that the specific circumstances of the protest require a longer period," he may lengthen the stay. ${ }^{151}$ Conversely, the Comptroller General may resolve those protests that he decides are "suitable for resolution" within forty-five calendar days of submission ${ }^{152}$ and may summarily dismiss any protest that he "determines is frivolous or which, on its face, does not state a valid basis for protest."153 The agency can override the stay upon a written finding by a responsible agency official that such action is required because of "urgent and compelling circumstances," or, in some cases, because "the best interests of the United States" compel such action. ${ }^{154}$

When President Reagan signed the Act into law, he objected to the stay provisions at issue, stating that they "unconstitutionally attempt to delegate to the Comptroller General of the United States, an officer of Congress, the power to perform duties and responsibilities that in our constitutional system may be performed only by officials of the executive branch."155 On this authority, the Director of the OMB instructed executive agencies to ignore the stay provisions in the Act, ${ }^{156}$ and thereby facilitate judicial review of the constitutional issue presented.

In resolving the resulting controversy, the United States Court of Appeals for the Third Circuit analyzed the executive branch's constitutional challenge to the Act under a general balancing test. ${ }^{157}$ Rely-

150 Id. $\S 3554(c)(1)$.

151 Id. § 3554(a)(1).

152 Id. $\S 3554(a)(2)$.

153 Id. § 3554(a)(3).

154 Id. § 3553(c)(2), (d)(2).

155 President's Statement on Signing H.R. 4170 into Law, 20 Weekly Comp. Pres. Doc. 1037 (July 18, 1984).

156 OMB Bulletin No. 85-8, at 2 (Dec. 17, 1984).

' 157 Ameron, 809 F.2d at 997-98; see also Lear Siegler, Inc. Energy Prods. Div. v. Lehman, 842 F.2d 1102, 1107 (9th Cir. 1988) (holding, similar to the holding in Ameron, that Congress can delegate authority to its constituent parts or to its agents as long as the acts to be performed are not "in the nature of a final disposition by the legislative agent or a directive to the executive actor to carry out the final disposition"). 
ing on the Nixon approach, ${ }^{158}$ it eschewed any "focus on the manner in which the Comptroller General acts to the exclusion of the power he wields." 159 The Court concluded that Congress's substantial interest in monitoring the procurement process clearly outweighs the potential intrusion into the executive's control of that process. ${ }^{160}$

Under any kind of balancing test, the Act would undoubtedly be upheld. ${ }^{161}$ Congress vested the Comptroller General with the power to modulate the stay in order to afford him sufficient time to make an informed recommendation while preventing the fait accompli that would result if the executive branch continued spending money on the contract prior to review. ${ }^{162}$ The stay is of relatively limited duration, and the executive branch can override the stay if government needs so dictate. ${ }^{163}$ Moreover, the intrusion is considerably less than that resulting if Congress instead had mandated a 180-day stay on all procurements. ${ }^{164}$

As in Chadha and Bowsher, however, a balancing test is simply inappropriate. The only question for resolution in Ameron should be whether the Comptroller General's exercise of authority to modify stays "binds" successful bidders and the executive branch. Although

158 Ameron, 809 F.2d at 996-98. Judge Garth, in concurrence, stated that Schor provided the pertinent standard to assess the asserted separation of powers violation:

[W] hether the stay power is constitutional depends upon whether there is an "aggrandizement of power at the expense of a coordinate branch." The answer in each case will depend, of course, upon whether the extent of the intrusion at stake is permissible in terms of the [Schor] test and is limited to that which is necessary to make an otherwise unobjectionable procedure workable.

Id. at 1001 (citation omitted).

159 Id. at 991.

160 Id. at 993-99.

161 Indeed, a balancing test makes little sense in this context. There is no dispute that Congress could accomplish at least its primary aim by providing for a longer statutory stay period preventing the agencies from commencing work on the contested contracts, see Alaska Airlines v. Brock, 107 S. Ct. 1476, 1483 \& n.12 (1987); Chadha, 462 U.S. at 935, just as there was no dispute that Congress could have passed statutory budget cuts in Bowsher.

162 H.R. Conf. Rep. No. 861, 98th Cong., 2d Sess. 1435-37 [hereinafter H.R. Conf. Rep. No. 861], reprinted in 1984 U.S. Code Cong. \& Admin. News 1445, 2123-25.

163 One court, however, has held that an agency's decision to override the contract is subject to judicial review. See Universal Shipping Co. v. United States, 652 F. Supp. 668, 674 (D.D.C. 1987), appeal docketed, No. 87-5210 (D.C. Cir. June 9, 1987).

164 Congress chose not to legislate such a stay in order to allow the Comptroller General the flexibility to dismiss frivolous protests at an earlier date and thereby permit the procurement to proceed. H.R. Conf. Rep. No. 861, supra note 162, at 1436-37, reprinted in 1984 U.S. Code Cong. \& Admin. News at 2124-25. 
the Comptroller General cannot bind the executive branch with respect to which contractor to select, his actions bind the executive branch and the private contractor with respect to when performance of the contract may proceed. ${ }^{165}$ Whether the Comptroller General shortens ${ }^{166}$ or lengthens the statutory stay period, the interested agency and contractor must discharge their contractual responsibilities as of that date. Just as in Bowsher, Congress's delegation of such authority to its agent implicates the concern for congressional accountability that underlies the separation of powers doctrine: to countenance the Comptroller General's role would be to allow an end

165 Perhaps if Congress passed a law directly authorizing the Comptroller General to determine the date that any government procurement should go forward, the violation would be clearer. In the Ameron context as well, however, the Comptroller General's actions similarly bind the procuring agency and the contractors, even if what triggers the timing decision is not a decision about what the timing should be per se, but the issuance of his decision on the merits of the protest. Moreover, the Comptroller General's determination of when to issue the decision reflects a type of policy judgment. His view of the merits of the protest obviously influences when he issues his decision - the easier the issue is, the quicker it can be decided, and if the protest is in fact "frivolous," the Comptroller General must issue his decision expeditiously to allow the procurement to go forward. Presumably, the result in Bowsher would not change if Congress directed that all budget plans be stayed pending the Comptroller General's determination of the wisdom of the executive's intended budget. Although Congress might be able to stop executive action to wait for an opinion from a third party, it cannot command the executive to await an opinion from its own agent.

In any event, it is clear that a balancing test is inappropriate. The dispositive determination is whether the Comptroller General's actions materially bind those outside the legislative branch.

166 At first blush, the power to shorten the stay period seems to work to the executive branch's benefit. The power to direct agencies to go ahead with the procurement, however, obviously binds agencies and, indeed, was designed by Congress in part to allow the Comptroller General influence over the contracting process: "because of [the Act], procurement officials may sometimes exercise their discretion in ways which are not required by the procurement laws, and which they would not otherwise have chosen, in order to minimize conflict with the Comptroller General." Ameron, 809 F.2d at 997.

A striking analogy can be seen in American Fed'n of Gov't Employees v. Pierce, 697 F.2d 303 (D.C. Cir. 1982). In Pierce, the court examined a provision of the Department of Housing and Urban Development's appropriation bill, which denied the agency the right to use available funds to conduct, plan, or implement any reorganization for a specified three-month period without prior approval of the House and Senate Committees on Appropriations. The court held that "the power to lift a congressionally-imposed restriction on the use of appropriated funds" could not be discharged by an agent of Congress and therefore invalidated the mechanism. Id. at 306.

The only difference in Ameron is that the Comptroller General not only can lift the stay because he thinks the protest is without merit (which is nearly identical to the situation in Pierce), but also can lift the stay by dint of issuing the recommendation more quickly (whether in favor of or opposed to the procurement). 
run around the bicameralism and presentment requirements. ${ }^{167}$ If Congress wishes to bind those outside its branch, it must do so in accordance with the constitutionally prescribed procedures.

\section{B. Separation of Powers Conflicts Arising from Executive Action}

The Constitution does not place comparable internal checks upon the executive branch. As discussed earlier, the framers presumably believed that such internal checks, aside perhaps from the appointments clause, were not necessary because the Constitution already circumscribed executive action considerably by confining it to the terms of congressional directives. ${ }^{168}$ Ensuring fidelity to congressional directives provided a measure of accountability because the legislative enactment itself had previously been "checked" in a constitutional sense. In addition, the need for dispatch in enforcing the laws militated against any cumbersome requirements delaying executive action. Generally, the executive may therefore act free of any procedural hurdles within the sphere of action allowed by Congress.

In comparison to cases involving procedural restraints on the legislative branch, cases in which the executive has failed to conform its acts to congressional direction have arisen only infrequently. Because the executive can usually rely upon at least implicit congressional approval for its actions, application of my theory to executive conduct has limited practical value. Viewing congressional measures as constitutional restraints on the President's ability to act, however, does help to clarify the appropriate separation of powers inquiry when such cases do arise. Balancing should play no role in their resolution.

The Supreme Court's opinion in Youngstown Sheet \& Tube Co. v. Sawyer ${ }^{169}$ remains the paradigmatic case on the balance of power between the executive and Congress. In response to a threatened nationwide steel strike, President Truman issued an Executive Order on April 8,1952, directing the Secretary of Commerce to seize and operate most steel plants. President Truman predicated the order not on any statute but on his constitutional responsibilities to "take care that the laws be faithfully executed" and to act as Commander in

167 But see Note, The Role of the Comptroller General in Light of Bowsher v. Synar, 87 Colum. L. Rev. 1539, 1559-63 (1987) (arguing that the Comptroller General can discharge any quasi-judicial function that can constitutionally be discharged in an article I forum).

168 See supra text accompanying notes $49-57$.

169343 U.S. 579 (1952). 
Chief of the Armed Forces. ${ }^{170}$ He feared that the strike could undermine the Korean War effort. ${ }^{171}$ The steel companies immediately sought injunctive relief. ${ }^{172}$

Although the Court was unable to agree on any one line of analysis, the decision is certainly consistent with the view that the Constitution prescribes the way each branch may act. For instance, Justice Black's opinion for the Court emphasized that

[i]n the framework of our Constitution, the President's power to see that the laws are faithfully executed refutes the idea that he is to be a lawmaker. The Constitution limits his functions in the lawmaking process to the recommending of laws he thinks wise and the vetoing of laws he thinks bad. ...

The President's order does not direct that a congressional policy be executed in a manner prescribed by Congress-it directs that a presidential policy be executed in a manner prescribed by the President. ${ }^{173}$

Justice Douglas also maintained in his concurring opinion that "the power to execute the laws starts and ends with the laws Congress has enacted." 174

In concurrence, the remaining justices emphasized that Congress, through the Labor Management Relations Act and the Defense Production Act, ${ }^{175}$ had already acted to shape and limit the executive's discretion in this area. For instance, Justice Burton stated that the President's action "invaded the jurisdiction of Congress" because Congress had previously qualified the President's authority to determine where and when to authorize the seizure of property in meeting such emergencies. ${ }^{176}$ Justice Frankfurter similarly stated that " $[t]$ he duty of the President to see that the laws be executed is a duty that

170 Id. at 674-75 (Vinson, C.J., dissenting) (citing Exec. Order No. 10340, 17 Fed. Reg. 3139 (1952)).

171 Id. at $668-80$ (Vinson, C.J., dissenting).

172 Id. at $582-83$.

173 Id. at $587-88$.

174 Id. at 633 . Justice Douglas emphasized that the branch of government constitutionally responsible to pay compensation for seizure is the branch that is constitutionally responsible to authorize seizure. Id. at 631-32.

175 See id. at 599-609 (Frankfurter, J., concurring) (discussing Labor Management Relations Act of 1947, ch. 120, 61 Stat. 136 (codified as amended in scattered sections of 29 U.S.C.); Defense Production Act of 1950, 64 Stat. 798 (codified as amended in scattered sections of 50 U.S.C. app.)).

176 Id. at 660 . He left open the question whether the President could have taken such action in the total absence of legislation covering the field. See id. at 659. 
does not go beyond the laws or require him to achieve more than Congress sees fit to leave within his power." "177 The opinions supporting the result in Youngstown therefore stress that Congress's articulation of policy objectives and its specification of the means for implementing those policies directly constrain presidential power.

Under a balancing test, however, the President's claim of emergency could have prevailed. ${ }^{178}$ Engaging in any such accommodation of interests would tilt the overall balance of power toward the executive because the executive's claim of an unforeseen emergency would in almost all situations override the prior congressional interest in channeling the executive's power. Recognizing the terms of congressional enactments as constitutional restraints on the executive's power therefore precludes use of a balancing test, and claims of inherent authority to disregard legislative direction trench upon our system of separated powers. ${ }^{179}$

177 Id. at 610 (quoting Myers v. United States, 272 U.S. 52, 177 (1926) (Holmes, J., dissenting)). Justices Frankfurter and Burton primarily stressed that Congress had constrained, and could legitimately constrain, the executive's discretion in taking emergency measures. Along with Justice Clark in concurrence, they relied upon the theory, articulated in Little v. Bareme (The Flying Fish), 6 U.S. (2 Cranch) 170 (1804), that Congress can limit the President's inherent authority in emergency situations by establishing procedures to channel and confine such exercise. On the record, they were convinced that Congress had so constrained the President's discretion in this instance. See Youngstown, 343 U.S. at 662 (Clark, J., concurring).

In contrast, Justice Jackson, in his famed concurring opinion, stated that the executive enjoys inherent authority to take actions in the public interest, even if at times those acts are contrary to articulated congressional intent. Although Justice Jackson's approach is inconsistent with what I believe to be the proper approach, which stresses constitutional restraints on action, he similarly emphasized that Congress in some cases could limit the executive's inherent authority, insofar as the President's powers "fluctuate, depending upon their disjunction or conjunction with those of Congress." Id. at 635. He likewise concluded that the prior congressional action precluded the President's action in this case. Id. at 644-46.

178 Indeed, the dissenting justices would have recognized a power in the President to take such exceptional measures as long as Congress was afforded the opportunity after the fact to countermand the executive action. In reliance upon United States v. Midwest Oil Co., 236 U.S. 459 (1915); In re Debs, 158 U.S. 564 (1895), see supra note 58; and In re Neagle, 135 U.S. 1 (1890), see supra note 58, Chief Justice Vinson stated that the President's constitutional responsibility to "take care" that the laws be faithfully executed included the power to seize the mills. See Youngstown, 343 U.S. at 701-04.

179 The executive's promulgation of a wide variety of other executive orders has continued to generate separation of powers concerns. Executive orders that are inconsistent with articulated congressional policy simply should not be enforced under the separation of powers doctrine. For instance, in United States v. East Motor Freight Sys., 564 F.2d 179 (5th Cir. 1977), the United States Court of Appeals for the Fifth Circuit held that the President cannot, by executive order, prevent private parties from utilizing a seniority system that is otherwise 
Viewed from this perspective, the impoundment controversy in the 1970's becomes easier to resolve. Impounding funds bypasses the safeguards on executive action placed in the Constitution. When Congress authorizes funds for a particular purpose, the President is constitutionally obligated to carry out that directive. ${ }^{180}$ Just as the legislative veto permitted Congress to effect policy without being directly accountable for its actions, impoundment gives the executive branch a tool to escape the constitutional restraints on its power.

Although the executive branch is checked by the terms of congressional enactments, the Constitution also contains more concrete "internal" checks on executive action. The appointments clause, for instance, despite the fact that it is frequently viewed as a check upon congressional power, serves to delimit the President's discretion. The President may not appoint important subordinates unless he obtains Senate confirmation of his choice, and only then if Congress has created the pertinent offices. ${ }^{181}$ Much as the President's veto power restrains Congress's legislation, the appointments clause's requirement of Senate ratification constrains the President in his selection of personnel in order to promote accountability. Accordingly, presidential efforts to bypass the appointments clause, even if supported by sound reasons of efficiency, should be scrutinized closely.

lawful under statute. Id. at 185; see also Liberty Mut. Ins. Co. v. Friedman, 639 F.2d 164, 169-72 (4th Cir. 1981) (denying enforcement to those parts of an executive order that were not authorized by Congress). The Supreme Court noted in Chrysler Corp. v. Brown, 441 U.S. 281 (1979), that "[t]he legislative power of the United States is vested in the Congress, and the exercise of quasi-legislative authority by governmental departments and agencies must be rooted in a grant of such power." Id. at 302. At a minimum, therefore, executive orders cannot contravene statutory directives.

Irrespective of whether the executive can generally issue orders in the absence of congressional authorization, it enjoys (as does Congress) the inherent right to issue circulars or orders in managing the executive branch itself, as long as such orders do not directly bind those outside the branch. The courts of appeals have refused to disturb such exercise of authority. See, e.g., United States Dep't of Health \& Human Servs. v. Federal Labor Relations Auth., 844 F.2d 1087, 1099-1100 (4th Cir. 1988) (en banc); Michigan v. Thomas, 805 F.2d 176, 187 (6th Cir. 1986); In re Surface Mining Regulation Litig., 627 F.2d 1346, 1357 (D.C. Cir. 1980); Independent Meat Packers Ass'n v. Butz, 526 F.2d 228, 236 (8th Cir. 1975), cert. denied, 424 U.S. 966 (1976). Of course, even without judicial enforcement, such orders are binding within the executive branch in the sense that any command from a superior is binding in light of the ever-present threat of dismissal.

180 See Louisiana v. Brinegar, 388 F. Supp. 1319, 1324-25 (D.D.C. 1975); Guadamuz v. Ash, 368 F. Supp. 1233, 1243-44 (D.D.C. 1973).

181 This scheme contrasts with that which existed in Great Britain, where the power to create offices was considered a royal prerogative. See E. Corwin, supra note 49 , at 85 . 
The Supreme Court has in fact carefully reviewed presidential actions that arguably bypassed the appointments clause procedures. In United States v. Corson, ${ }^{182}$ the Supreme Court held that a discharged army officer could not be restored to his former position. merely by a subsequent presidential revocation of the order of dismissal. The President had argued that, because he exclusively held the power of dismissal, he likewise had the power to revoke the prior order. The Court, however, reasoned that the vacancy so created could only be filled by a new and original appointment, to which the advice and consent of the Senate was necessary:

The death of the incumbent could not more certainly have made a vacancy than was created by President Lincoln's order of dismissal from the service. And such vacancy could only have been filled by a new and original appointment, to which, by the Constitution, the advice and consent of the Senate were necessary . . . . ${ }^{183}$

Similarly, in Mimmack v. United States, ${ }^{184}$ the Court held that when an army captain's resignation had been accepted, the officer could not be reinstated without a new nomination and confirmation. ${ }^{185}$ No balancing was undertaken; the Court concluded that the President must meet the provisions of the appointments clause even if the infraction was in some sense de minimis. The President could only exercise his powers pursuant to the procedures set out in the Constitution. ${ }^{186}$

In addition to the appointments clause, Congress's ability to override a veto also checks the President's actions by ensuring that the

182114 U.S. 619 (1885).

183 Id. at 622.

18497 U.S. 426 (1878).

185 Id. at 437; see also Blake v. United States, 103 U.S. 227, 237 (1881) ("Having ceased to be an officer in the army, he could not again become a post-chaplain, except upon a new appointment, by and with the advice and consent of the Senate." (citing Mimmack, 97 U.S. at 426)).

186 Former Attorney General Edwin Meese's appointment of William Bradford Reynolds as Counselor to the Attorney General in 1986 raised similar constitutional concerns. The Senate refused to confirm Reynolds's appointment when he had been nominated in the previous year to be Associate Attorney General. N.Y. Times, June 28, 1985, at 1, col. 1. Although Reynolds could, consistent with the appointments clause, be appointed to an office-such as Counselor to the Attorney General-for which Senate confirmation is unnecessary, the Attorney General reportedly vested such new duties in the office as to make Reynolds a de facto Associate Attorney General. Williams, In his Mind, Not his Heart, Wash. Post, Jan. 10, 1988 (Magazine), at 15-16. Although the additional duties may largely have been advisory, the Attorney General's action arguably was inconsistent with the "internal" checks on executive branch action. 
President will be accountable for his exercise of the veto power. If the President disagrees with a congressional enactment, his constitutional recourse is to veto the enactment, and that veto is subject to an override by a two-thirds vote in both houses of Congress. ${ }^{187}$ The possibility of an override, thetefore, serves as a check on the President, not only limiting his power, but also promoting accountability for his actions. ${ }^{188}$

Thus, although the President may enjoy substantial inherent power in foreign affairs, and, as a statutory matter today, enjoys nearly limitless power to address national emergencies, ${ }^{189}$ substantial constraints still exist. Congress may, if it so chooses, remove the virtual blank check it has afforded the President to act in emergencies, or, as in Youngstown, it may limit the manner in which the President can proceed in such emergencies. Moreover, the appointments clause and congressional capacity to override presidential vetoes are more palpable restraints on the executive's action, making the President accountable for his selection of personnel and use of the veto power. Consequently, although no restrictions similar to the bicameralism and presentment requirements limit the executive's mode of action, the need for congressional authorization and internal limits like the appointments clause circumscribe the executive branch.

\section{Separation of Powers Conflicts Arising From Judicial Acts Outside Cases or Controversies}

The case or controversy requirement in article III provides the analogous restraint upon the judiciary's mode of action. The judiciary generally cannot take action binding those outside its branch

187 The Federalist No. 69, supra note 21, at 416 (A. Hamilton).

188 Presidential claims of broad powers to exercise the "pocket veto," U.S. Const. art. I, § 7, cl. 2, therefore, threaten the constitutional structure. Exercise of the pocket veto allows the President to veto legislation without accepting direct responsibility for his actions, a result diametrically at odds with the framers' decision to ensure presidential accountability by permitting Congress to override any veto. See, e.g., Wright v. United States, 302 U.S. 583 (1938) (three-day recess by Senate did not constitute an adjournment of Congress for purposes of the pocket veto); Barnes v. Klein, 759 F.2d 21, 31 (D.C. Cir. 1984) (invalidating attempted pocket veto), vacated as moot sub nom. Burke v. Barnes, 479 U.S. 361 (1987); Kennedy v. Sampson, 511 F.2d 430, 442 (D.C. Cir. 1974) (same); 2 J. Story, supra note 25, \& 888, at 354 55 ("[T]he president might effectually defeat the wholesome restraint, thus intended, upon his qualified negative, if he might silently decline to act after a bill was presented to him for approval or rejection.").

189 See supra note 60 and accompanying text. 
except in the context of a case or controversy. The prohibitions against advisory opinions and performance of "nonjudicial" business flow from that constitutional restraint on the judiciary.

At the same time, the case or controversy requirement serves a function quite different from the restraints on coordinate branches of government: it protects the judiciary from excessive involvement in the affairs of the coordinate branches of government. Judicial independence can be maintained by generally confining the judiciary to one permissible mode of action.

Because the case or controversy limitation represents an "internal" check on the judiciary, as well as a protection, balancing should play no part in evaluating measures that force the judiciary to overstep that limitation. Legislation that requires judges in their official capacity to take action outside of the traditional judicial context cannot be salvaged by dint of the conceivably weighty legislative (or judicial) interests underlying the enactment. ${ }^{190}$

\section{Origins of Limits on Judicial Action}

The Supreme Court first confronted legislation requiring judges to act outside cases and controversies several years after the ratification of the Constitution. In response to petitions from Revolutionary War veterans, Congress in 1792 passed a bill directing the judges on the federal circuit courts to determine what pensions should be paid, subject to oversight by the Secretary of War. ${ }^{191}$ The Act provided that "[t]he circuit court, upon receipt of the proofs aforesaid, shall forthwith proceed to examine into the nature of the ... disability of such applicant, and having ascertained the degree thereof, shall certify the same, and transmit the result of their inquiry ... to the Secretary at War."192 When Hayburn petitioned the United States Circuit Court for the District of Pennsylvania, the judges declined to entertain juris-

190 Judges rarely act in the absence of a case or controversy unless another branch-usually Congress-authorizes such conduct. Congress's sanction, however, removes neither the threat to individual liberty nor the threat to the system of separated powers against which the "case or controversy" requirement protects. At the same time, the congressional sanction threatens judicial independence by entangling the judiciary in "nonjudicial" functions.

191 Act of March 23, 1792, ch. 11, 1 Stat. 243.

192 Id. at 244. 
diction over the claim. ${ }^{193}$ One other circuit court similarly declined to undertake the duties prescribed in the Act, and the two courts, along with members of another circuit, wrote to the President explaining why, in their view, it would be unconstitutional to rule on the pension claims. ${ }^{194}$

The courts stressed primarily that the Act threatened judicial independence. For instance, the Pennsylvania circuit court explained that "[i]t is a principle important to freedom, that in government, the judicial should be distinct from, and independent of, the legislative department. To this important principle, the people of the United States, in forming their Constitution, have manifested the highest regard."195 According to the court, however, because the court's judgments under the Act might "have been revised and controuled by the legislature, and by an officer in the executive department," the Act was "inconsistent with the independence" of the judiciary. ${ }^{196}$ The United States Circuit Courts for the District of New York and for the District of North Carolina emphasized the threat to the separation of powers that could arise from allowing the Secretary of War to review the courts' dispositions of pension requests. Although there was nothing inherently nonjudicial about adjudicating claims of war veterans, the possibility that the Secretary of War would revise the courts' findings undermined judicial finality and therefore violated the constitutional structure. ${ }^{197}$

Yet the courts also emphasized that the Act impermissibly required the judiciary to act through other than the constitutionally prescribed means. The North Carolina circuit court noted that "the ultimate basis of each [branch] is the Constitution only within the limits of which each department can alone justify any act of authority."198 Because the duties prescribed in the Act did not fall within the constitutional parameters, the court qua court ${ }^{199}$ could not act on the peti-

193 See Farrand, The First Hayburn Case, 1792, 13 Am. Hist. Rev. 281 (1908). Farrand concluded that this case represented the first instance in which a federal court ruled (at least implicitly) that a congressional enactment was unconstitutional. Id. at 285.

194 Hayburn's Case, 2 U.S. (2 Dall.) 409 (1792).

195 Id. at 411 n.2.

196 Id.

197 Id. at $410-12$ \& n.2.

198 Id. at 412 n.2.

199 Some of the judges suggested that a different issue would arise if Congress had authorized the judges in their private capacity to fill the role of commissioners. See infra note 
tion. The Pennsylvania circuit court asserted that "[b]ecause the business directed by this act is not of a judicial nature[,] [i]t forms no part of the power vested by the constitution in the courts of the United States."200 Similarly, the New York circuit court concluded that "neither the Legislative nor the Executive branches can constitutionally assign to the Judicial any duties, but such as are properly judicial, and to be performed in a judicial manner."201 Thus, although the judges of the three circuit courts, including five justices of the Supreme Court, may have viewed the Act as a threat to their independence, they also recognized that performing the tasks under the Act would be incompatible with the constitutional limitations on how they could act. ${ }^{202}$

One year later, the Supreme Court declined Secretary of State Jefferson's request for an advisory opinion concerning legal questions

204. The Supreme Court later determined, however, that the Act in question did not authorize the judges to perform such extrajudicial functions in their individual capacities. See United States v. Yale Todd (U.S. Feb. 17, 1794) (unreported but discussed in United States v. Ferreira, 54 U.S. (13 How.) 40, 52-53 (1852)); Slonim, Extrajudicial Activities and the Principle of the Separation of Powers, 49 Conn. B.J. 391, 403-06 (1975).

200 Hayburn's Case, 2 U.S. (2 Dall.) at 411 n.2.

201 Id. at 410 n.2.

202 Judges' responses toward discharge of administrative tasks were not uniform in those first years, see Wheeler, Extrajudicial Activities of the Early Supreme Court, 1973 Sup. Ct. Rev. 123, 131-39, and Congress directed judges to discharge several administrative chores in addition to the pension duties. See, e.g., Act of Jan. 29, 1795, ch. 20, §§ 1-2, 1 Stat. 414-15 (directing judges to assess applicants for naturalization); Act of May 26, 1790, ch. 12, 1 Stat. 122-23 (requiring district judges to assess petitions for remissions of forfeitures).

The prevailing view among judges, however, condemned congressional efforts to assign such administrative duties to judges, at least in their official capacity. The Supreme Court in the early part of this century accordingly refused to review decisions of the District of Columbia Court of Appeals in which that court acted as an administrative body, and in which review by the Supreme Court was plenary. As the Court explained in Keller v. Potomac Elec. Power Co., 261 U.S. 428 (1923), "[s]uch legislative or administrative jurisdiction . . can not be conferred on this Court either directly or by appeal." Id. at 444; see also Federal Radio Comm'n v. General Elec. Co., 281 U.S. 464 (1930) (following Keller); Postum Cereal Co. v. California Fig Nut Co., 272 U.S. 693 (1927) (same). Although the Supreme Court later held, seemingly inconsistently, that judges on the D.C. court were article III judges, the Court predicated its decision on the narrow ground of Congress's unique authority to legislate for the District of Columbia under article I, section 8, and the Court never wavered in its conclusion that it could not discharge those same duties. O'Donoghue v. United States, 289 U.S. 516, 546-48 (1933); see also Chicago \& S. Air Lines v. Waterman S.S. Corp., 333 U.S. 103, 114 (1948) (holding that the judiciary could not pass on Civil Aeronautics Board awards of international air routes because any decision would have ultimately been subject to approval by the President). 
arising out of the hostilities between France and Great Britain. The justices wrote the President,

We have considered the previous question stated in a letter written by your direction to us by the Secretary of State on the 18th of last month, [regarding] the lines of separation drawn by the Constitution between the three departments of government. These being in certain respects checks upon each other, and our being judges of a court in the last resort, are considerations which afford strong arguments against the propriety of our extrajudicially deciding the questions alluded to . . . ${ }^{203}$

Whether it derives from a constitutional requirement or prudential considerations, the ban against advisory opinions reinforces the limits on the judiciary's ability to act. ${ }^{204}$ Just as the judges in Hayburn's

203 Letter from Chief Justice John Jay and the Associate Justices of the Supreme Court to President George Washington (Aug. 8, 1793), quoted in P. Bator, P. Mishkin, D. Shapiro \& H. Wechsler, Hart \& Wechsler's The Federal Courts and the Federal System 65 (2d ed. 1973); see also 3 J. Story, supra note $25, \S 1565$, at 420 (the judiciary "can be called upon only to decide controversies brought before them in legal form"). Justice Frankfurter later commented that rendering advisory opinions would "involve the judges too intimately in the process of policy and thereby weaken confidence in the disinterestedness of their judicatory functions." 1 Encyclopaedia of the Social Sciences 478 (1930).

204 At the same time, individual judges were apparently not constrained from aiding the executive branch on a voluntary basis, and indeed, John Jay served simultaneously as Chief Justice and envoy to Great Britain. But cf. 1 C. Warren, The Supreme Court in United States History 119-21 (1926) (noting that many at the time condemned Jay's appointment as contrary to the spirit of the Constitution and warned that the independence of the judiciary could be compromised). When judges are not acting in an official capacity, the case or controversy limitation does not directly constrain their conduct. For instance, judges should be allowed to write law review articles and give speeches, even if the content of such commentary may resemble an advisory opinion. On the other hand, judges should not necessarily be able to serve, even if voluntarily, on the National Security Council or on the FTC, because discharge of such tasks would compromise either the appearance or reality of judicial independence. Judges who become too closely aligned with the interests of another branch cannot be expected to maintain their impartiality in adjudicating that other branch's interests, and the public at large may lose faith in the judiciary's independence. But, because some voluntary service is permitted, the propriety of judges' voluntary discharge of tasks for another branch must be assessed on a flexible, case-by-case basis. See supra text accompanying notes 122-39.

For instance, challenges were recently raised against the voluntary participation by judges on the President's Commission on Organized Crime, which was formed to advise the executive with respect to enhanced criminal law enforcement efforts. The limited nature of the Commission's functions minimizes the concerns of compromising judicial independence and threatening the impartial adjudication of cases and controversies. Compare In re President's Comm'n on Organized Crime (Subpoena of Scarfo), 783 F.2d 370, 377-78 (3d Cir. 1986) (the limited and voluntary nature of judicial participation on the Commission mitigated separation of powers concerns) with In re President's Comm'n on Organized Crime (Subpoena of 
Case refused to advise the Secretary of War concerning the rights of pensioners except in the context of a case or controversy, the justices on the Supreme Court refused to advise the executive branch with respect to questions of international law in the absence of a properly constituted judicial case. ${ }^{205}$ Except through cases and controversies, therefore, judges acting in their official capacity could not be required to advise coordinate branches of government. Instead of considering the possibly weighty interests of the other branches, the focus was on the dimensions of the "internal" check itself. Indeed, unlike the restraints on the legislative branch, the case or controversy limitation prescribes when the judiciary can discharge duties at the behest of coordinate branches of government.

Moreover, although confining judicial power to resolution of cases and controversies protects the independence of the judiciary, it also prevents judicial encroachment. Judges acting in their judicial capacity lack the power to bind individuals except in the context of a properly constituted case. ${ }^{206}$ As Chief Justice Marshall-no enemy of

Scaduto), 763 F.2d 1191, 1197 (11th Cir. 1985) (finding that the Commission posed separation of powers difficulties despite voluntary nature of judges' participation on the Commission). See generally Mason, Extra-Judicial Work for Judges: The Views of Chief Justice Stone, 67 Harv. L. Rev. 193 (1953) (detailing Stone's adamant refusal to engage in governmental activities outside of his responsibilities on the Court); Slonim, supra note 199, at 395 (arguing that the separation of powers principle relates only to the performance of official acts); Note, Separation of Powers and Judicial Service on Presidential Commissions, 53 U. Chi. L. Rev. 993 (1986) (arguing that voluntary participation, even with respect to advice, can give rise to intractable separation of powers problems).

205 In Muskrat v. United States, 219 U.S. 346 (1911), the Supreme Court further emphasized that the judiciary must " "carefully abstain from exercising any power that is not strictly judicial in its character, and which is not clearly confided to it by the Constitution," " id. at 355 (quoting Gordon v. United States, 117 U.S. 697, 706 (1864)), because "the exercise of the judicial power is limited to 'cases' and 'controversies." " Id. at 356.

206 See generally Marbury v. Madison, 5 U.S. (1 Cranch) 137 (1803) (judges' power derives from duty to decide cases before them). An interesting example is presented by contempt citations issued against nonparties who have allegedly violated prior orders of the court. Unless nonparties act in concert with those subject to the court's orders, courts simply cannot, consistent with the separation of powers doctrine, punish such action as contempt. Compare G. \& C. Merriam Co. v. Webster Dictionary Co., 639 F.2d 29, 35 (1st Cir. 1980) (nonparty can be held in contempt for disobeying injunction only for actively participating in a party's violation) and Alemite Mfg. Co. v. Staff, 42 F.2d 832, 833 (2d Cir. 1930) (when suit had been dismissed against one defendant, that defendant could not be held in contempt unless he "helped to bring about" a former codefendant's violation of injunction) with Waffenschmidt $v$. Mackay, 763 F.2d 711, 717 (5th Cir. 1985) (emphasizing requirement of knowingly acting in concert with other parties) and United States v. Hall, 472 F.2d 261, 267-68 \& n.4 (5th Cir. 1972) (finding "active concert or participation" in willful violation of ex parte order issued 
federal judicial power-explained,

By the constitution, the judicial power of the United States is extended to all cases in law and equity, arising under the constitution, laws and treaties of the United States; but the resolutions [under discussion in Congress] declare the judicial power to extend to all questions arising under the constitution, treaties, and laws of the United States. . . . A case in law or equity was a term well understood, and of limited signification. ... If the judicial power extended to every question under the constitution, it would involve almost every subject proper for legislative discussion and decision .... The division of power [among the branches] could exist no longer, and the other departments would be swallowed up by the judiciary. ${ }^{207}$

Although viewing the "case or controversy" requirement in this light does not elucidate the troubling question of what actually is an article III case or controversy, ${ }^{208}$ it does emphasize that questions of justiciability are properly analyzed as separation of powers issues. As the Supreme Court has stated, the case or controversy limitation prescribes the "role assigned to the judiciary in a tripartite allocation of power to assure that the federal courts will not intrude into areas committed to the other branches of government."209 Moreover, because the "case or controversy" limitation not only delimits the scope of judicial power, but also preserves its independence, courts

against undefined class in school desegregation case). Analogous issues are presented by the judiciary's efforts, outside of its contempt power, to punish attorneys. See, e.g., Eash v. Riggins Trucking Inc., 757 F.2d 557, 560 (3d Cir. 1985) (en banc) (upholding, by a divided court, authority of district court to impose on attorney sanctions that had not been authorized by statute or rule).

207 Speech of the Honorable John Marshall to the House of Representatives, reprinted in J. Oster, The Political and Economic Doctrines of John Marshall 238 (1914).

208 In addition, this analysis does not address a myriad of other separation of powers questions involving judicial acts taken in the context of what are admittedly cases or controversies. For instance, focusing upon the requirement of a case or controversy will not resolve the propriety of the judiciary's power to fashion federal common law, see, e.g., In re Debs, 158 U.S. 564 (1895), or its power to issue structural injunctions, see, e.g., Hills v. Gautreaux, 425 U.S. 284 (1970).

209 See Flast v. Cohen, 392 U.S. 83, 95 (1968); see also Allen v. Wright, 468 U.S. 737, 750 (1984) ("The "case or controversy' requirement defines with respect to the Judicial Branch the idea of separation of powers on which the Federal Government is founded."). Although the Allen decision has been criticized on many grounds, the Court was plainly correct in viewing the standing inquiry as a part of the separation of powers scheme. That insight, however, in no way dictated the outcome in the case. See Nichol, Abusing Standing: A Comment on Allen $v$. Wright, 133 U. Pa. L. Rev. 635 (1985) (arguing that separation of powers considerations should not affect application of traditional three-part test for standing). 
should approach legislative or executive actions conferring nonjudicial powers on the judiciary with particular suspicion.

\section{Some Recent Cases Exploring Limits on Judicial Action}

In two recent instances, individuals have challenged Congress's decision to vest in the judiciary arguably nonjudicial functions. In one, the Judicial Councils Reform and Judicial Conduct and Disability Act of 1980 ("Judicial Conduct Act"), ${ }^{210}$ Congress set up machinery to facilitate judges' efforts to "put their own house in order."211 In the other, the Comprehensive Crime Control Act of 1984, ${ }^{212}$ Congress created a Commission comprising both judges and nonjudges to issue sentencing standards binding in all federal criminal cases. Because both statutes assign to the judiciary functions unconnected to particular cases and controversies, ${ }^{213}$ they potentially violate the constitutional restraints on the judiciary's mode of action. A balancing test is inappropriate in determining whether there has been such a violation. Although understanding the case or controversy requirement as a limitation on judicial action is only marginally helpful in resolving the first challenge, it should be dispositive in the second.

\section{a. Establishment of a Peer Review Mechanism}

\section{Under the Judicial Conduct Act, Congress established a uniform}

\footnotetext{
21028 U.S.C. $\S \S 331,332,372(c), 604$ (1982 \& Supp. IV 1986).

211 Chandler v. Judicial Council of Tenth Circuit, 398 U.S. 74, 85 (1970).

212 Pub. L. No. 98-473, tit. II, 98 Stat. 1976 (codified in scattered sections of 18 U.S.C.).

213 Through exercise of the contempt power, the judiciary arguably binds litigants who are outside the judicial branch. Historically, however, that power has been viewed as inextricably intertwined with the power to hear article III cases and controversies. See United States v. Hudson \& Goodwin, 11 U.S. (7 Cranch) 32, 34 (1812) (judges must use the power "from the nature of their institution"); Young v. United States ex rel. Vuitton et Fils S.A., 107 S. Ct. 2124,2133 (1987) (the contempt power is inherent in article III courts and cannot be abrogated, even though the manner in which a court exercises such power may be regulated by Congress and the Supreme Court). See generally Frankfurter \& Landis, Power of Congress over Procedure in Criminal Contempts in "Inferior" Federal Courts-A Study in Separation of Powers, 37 Harv. L. Rev. 1010, 1020-23 (1924) (contempt power is permissible constitutional enhancement of courts' inherent authority to protect their procedures).

Another exception to the case or controversy requirement may be the Supreme Court's power under the Rules Enabling Act of 1934, ch. 651, 48 Stat. 1064 (1934) (codified as amended in 28 U.S.C. $\$ 2072$ (1982)), to promulgate rules governing procedure in the federal courts. This power has been upheld only on the theory that the Supreme Court's exercise of such authority cannot alter the substantive rights of individuals. See infra notes 242-49 and accompanying text.
} 
system to handle complaints of judges' misconduct. ${ }^{214}$ It lodged the authority to administer the system in the judicial councils of each circuit and in the Judicial Conference of the United States. ${ }^{215}$ Upon receipt of a complaint that a judge has engaged in conduct prejudicial to the business of courts, the chief judge of the circuit may empanel a special investigating committee to inquire into the matters alleged. ${ }^{216}$ After conducting an investigation, during which it may exercise the subpoena power, ${ }^{217}$ the committee must file with the judicial council a written report detailing the committee's findings and recommending the course of action that the judicial council should pursue. ${ }^{218}$

After reviewing the committee's report, the judicial council may conduct any further investigation it considers necessary. ${ }^{219}$ It then "shall take such action as is appropriate to assure the effective and expeditious administration of the business of the courts within the circuit," including privately or publicly censuring the judge, temporarily ceasing to assign cases to the judge, certifying the judge as disabled, or requesting the judge to retire voluntarily. ${ }^{220}$ The judge, the judicial council, or the complainant can request the Judicial Conference to review the decision of the council. ${ }^{221}$

In addition, if the council determines after an investigation that an article III judge ${ }^{222}$ has engaged in conduct "which might constitute one or more grounds for impeachment," it is authorized to certify such a determination to the Judicial Conference. ${ }^{223}$ In turn, the Conference may conduct any investigation that it deems appropriate; if it then "concurs in the determination of the council, or makes its own

214 In large measure, this peer review mechanism mirrors what had already been adopted by the Judicial Conference and many circuit councils on their own initiative. See Judicial Tenure and Discipline, 1979-1980: Hearings Before the Subcomm. on Courts, Civil Liberties, and the Administration of Justice of the House Comm. on the Judiciary, 96th Cong., 1st-2d Sess. 53106 (1980) (statements of Hon. James R. Browning, Chief Judge, 9th Cir.; Hon. J. Clifford Wallace, 9th Cir.; and Hon. Elmo B. Hunter, W.D. Mo., Judicial Conference of the United States).

21528 U.S.C. § 372(c) (1982 \& Supp. IV 1986).

216 Id. § 372(c)(4) (1982).

217 Id. § 372(c)(9)(A).

218 Id. $\S 372(\mathrm{c})(5)$.

219 Id. $\S 372(\mathrm{c})(\mathrm{G})(\mathrm{A})$.

220 Id. $\$ 372(\mathrm{c})(6)(\mathrm{B})$.

221 Id. \& 372(c)(7)(A), (10).

222 The peer review mechanism also handles complaints against bankruptcy judges, who are article I officials, and magistrates. Id. § 372(c)(1).

223 Id. § 372(c)(7)(B). 
determination, that consideration of impeachment may be warranted, it shall so certify and transmit the determination and the record of proceedings to the House of Representatives."224

In seeking to derail an investigation under the Judicial Conduct Act, Judge Alcee L. Hastings alleged in part that the Act violated the separation of powers doctrine by impermissibly delegating non-article III business to the judiciary. ${ }^{225}$ Of relevance to this discussion, he argued that the Act unconstitutionally requires judges to act as legislative commissioners in deciding whether to recommend impeachment to the House of Representatives.

Without question, the Judicial Conduct Act imposes upon the judicial branch duties unconnected with cases and controversies. Any such delegation, as in Hayburn's Case, raises the questions whether the judiciary can administer such functions and still retain its independence, and whether those functions impinge upon either the rights of individuals or the prerogatives of a coordinate branch. In particular, the requirement that the judiciary report its impeachment recommendation to the House raises substantial separation of powers concern.

First, the general delegation of administrative responsibilities under the Judicial Conduct Act binds only those within the branch-primarily the judges under investigation. Although the complainant certainly has an interest in the proceeding, and subpoenas may be issued to third parties, the legal rights of the complainant and third parties, assuming compliance with the subpoenas, will not be affected. ${ }^{226}$ In contrast, if the Act authorized punishment of those who acted in concert with judicial officials, it would be unconstitutional insofar as it

224 Id. § 372(c)(8).

225 See Hastings v. Judicial Conference of United States, 829 F.2d 91, 103-04 (D.C. Cir. 1987), cert. denied, 108 S. Ct. 1487 (1988); In re Certain Complaints Under Investigation by Investigating Comm. of Judicial Council of Eleventh Circuit, 783 F.2d 1488, 1510-12 (11th Cir. 1986) [hereinafter In re Complaints], cert. denied, 477 U.S. 904 (1986); Hastings v. Judicial Conference of United States, 770 F.2d 1093, 1100 (D.C. Cir. 1985), cert. denied, 477 U.S. 904 (1986). Judge Hastings challenged the Act on numerous other grounds, primarily that the Act on its face infringed upon the independence of individual judges and that the Act as applied violated his right to due process.

226 Each branch has a legitimate interest in issuing subpoenas to acquire pertinent information, and individuals have a duty to comply with subpoenas, regardless of whether issued by Congress, the judiciary, or the executive branch. See, e.g., Blair v. United States, 250 U.S. 273, 280-81 (1919); In re Complaints, 783 F.2d at 1520-21; FTC v. Ernstthal, 607 F.2d 488, 490 (D.C. Cir. 1979). 
purported to empower judges to determine the legal rights of persons who are not part of the judicial branch and not parties to a case or controversy.

Moreover, judges ordinarily perform such "housekeeping" duties in their own interests, not at the behest of other branches. There is little dispute that the judiciary may discharge the administrative authority necessary to conduct its own business without running afoul of the separation of powers doctrine. To function as an independent branch, judges must make rules to govern the proceedings before them and to ensure the efficacious flow of judicial business, ${ }^{227}$ and must appoint subordinate officials to aid in their work. ${ }^{228}$ Like Congress and the executive, the judiciary therefore enjoys the inherent authority to manage its own branch.

Although Congress can facilitate the judiciary's discharge of such administrative functions, it conceivably could fashion duties in ways undermining judicial independence. Although that hypothetical case lies outside this discussion, the key consideration would be whether Congress had left operation of the administrative duty in the judiciary's discretion. If the judiciary can choose whether to discipline a judge, for example, then it retains effective control. In other words, to quote Madison, if the judiciary retains the "necessary constitutional means and personal motives to resist encroachments of the others,"229

227 See Wayman v. Southard, 23 U.S. (10 Wheat.) 1, 42 (1825) (sanctioning the first Congress's decision to vest the judiciary with the power to " 'make and establish all necessary rules for the orderly conducting business in the said Courts, provided such rules are not repugnant to the laws of the United States' " (quoting Judiciary Act of 1789, ch. 20, § 17, 1 Stat. 73, 83)); Chandler v. Judicial Council of Tenth Circuit, 398 U.S. 74, 86 n.7 (1970) (approving Congress's decision to vest administrative authority in circuit judicial councils); Fidelity Mortgage Investors v. Administrative Office of U.S. Courts, 690 F.2d 35, 39 (2d Cir. 1982) (United States Judicial Conference acting "as an auxiliary of the courts" is exempt from the rulemaking provisions of the Administrative Procedure Act), cert. denied, 462 U.S. 1106 (1983); Imperial " 400 " Nat'l, Inc. v. Judicial Council of Third Circuit, 481 F.2d 41, 45 (3d Cir.) (broadly construing judicial council's administrative authority within the circuit), cert. denied, 414 U.S. 880 (1973). But see Note, Unnecessary and Improper: the Judicial Councils Reform and Judicial Conduct and Disability Act of 1980, 94 Yale L.J. 1117 (1985) (arguing that administrative duties prescribed in the Judicial Conduct Act impinge upon judicial independence).

228 See In re Hennen, 38 U.S. (13 Pet.) 230 (1839) (appointing clerk of court).

229 The Federalist No. 51, supra note 21, at 321-22 (J. Madison). As with the contempt power, see supra note 99 , Congress may regulate matters falling within the inherent power of article III courts. Congress and the courts, to a certain extent, therefore enjoy concurrent authority over the manner in which judges may discipline themselves or engage in rulemaking. 
such delegation of administrative duties is appropriate. ${ }^{230}$ Congress plainly left the judiciary with control over the general delegation in the Judicial Conduct Act.

Nevertheless, the specific requirements that the Judicial Conference determine whether "consideration of impeachment may be warranted" and that it certify such "determination ... to the House of Representatives"231 do present serious separation of powers questions. Two interrelated problems are implicated: first, whether Congress may require the judiciary to report its proceedings to Congress; and second, whether Congress may require that the judiciary make findings concerning the propriety of impeachment.

By itself, mandatory reporting is not problematic. If Congress required the Conference to transmit only the results of its inquiry and the record of its proceedings, then no intractable separation of powers problem would arise. Reporting requirements have been upheld in a variety of contexts, ${ }^{232}$ and the report here concerns information that the Judicial Conference would otherwise learn in the course of conducting judicial business. Although judges in a sense would be required to discharge the "nonjudicial" task of making a report, congressional access to information is indispensable to fulfillment of its article I responsibilities. ${ }^{233}$ Moreover, at least in most cases, there is no reason to believe that making such reports would compromise a notion of "judicial privilege."234 Thus, a mandatory reporting requirement does not pose the same problems identified in Hayburn's Case and its progeny.

The real difficulty arises in resolving the second question. The judiciary, in investigating a complaint solely for its own purposes, would be unlikely to consider whether impeachment is warranted, a decision

See supra note 213. In this Article, I do not purport to address the nuances of that concurrent authority.

230 Conversely, if Congress mandated certain punishments, or if Congress in fashioning a scheme undermined judges' ability to resolve cases and controversies, cf. United States v. Klein, 80 U.S. (13 Wall.) 128 (1872) (arguably holding that Congress cannot bind the judiciary by prescribing rules of decision in pending cases), then even a peer review mechanism might violate the separation of powers doctrine.

23128 U.S.C. \& 372(c)(8) (1982).

232 See, e.g., Alaska Airlines v. Brock, 107 S. Ct. 1476, 1482 (1987); Sibbach v. Wilson \& Co., 312 U.S. 1, 15 (1941).

233 See supra note 99.

234 See In re Complaints, supra note 225 , at 1517-25. 
that is constitutionally committed to the House of Representatives. Rather, the issue for judicial consideration under the Judicial Conduct Act is whether the conduct of the judge under investigation was "prejudicial to the conduct of judicial business," a determination that may be related, but is certainly not identical, to whether impeachment may be warranted. Although the question seems quite close, requiring the judiciary to make the impeachment recommendation violates the case or controversy limitation on judicial action-the judiciary would be forced to deliberate on a matter that, although of concern to the judiciary, is reserved to the House of Representatives. Any group of judges as individuals must be free to recommend impeachment to the House on their own initiative, but making judges serve in effect as legislative commissioners is constitutionally impermissible. ${ }^{235}$

One may also analogize the certification requirement to a request for an advisory opinion. Requiring the judiciary to determine whether "impeachment may be warranted" is really no different from requiring the judiciary to consider whether a proposed piece of legislation is constitutional or, for that matter, whether a pension should be paid. Thus, the ban on advisory opinions, which is an outgrowth of the "case or controversy" requirement, suggests that Congress cannot require judges to consider whether "impeachment may be warranted." Otherwise, the independence of the judiciary could be threatened as it became embroiled in the affairs of a coordinate branch.

In any event, Congress's delegation of such responsibility to the judiciary cannot be assessed by means of a balancing test. Rather, what is required is a determination of whether mandatory judicial

235 To avoid the constitutional question, the D.C. Circuit found that, despite use of the phrase "shall . . . certify," Congress meant only to encourage the Conference to make such a certification in the proper circumstances. See Hastings v. Judicial Conference of United States, 829 F.2d 91, 101-03 (D.C. Cir. 1987). Construing the certification request as permissive does remove the constitutional concern, even though requiring the Judicial Conference to transmit the final report to the House might have the same practical effect on the probability of impeachment as requiring certification as to whether impeachment may be warranted. Congress could authorize any entity, in its discretion, to communicate to Congress its belief that impeachment may be warranted. If the judiciary need not consider whether impeachment is warranted, and need not, therefore, certify any such findings to the House of Representatives, then the provision is harmless from a separation of powers perspective.

In dissent, however, Judge Buckley reasoned that, even if the provision is construed to be discretionary, the mechanism in effect coerces the judiciary to make such a certification. Id. at 110. 
participation in impeachment matters violates the purposes of the "case or controversy" limitation. It is certainly not enough to observe that Congress has a legitimate interest in overseeing judicial conduct and in acquiring information pertinent to the impeachment inquiry, and that such interests outweigh any theoretical infringement upon the judiciary's independence. Otherwise, Congress could incrementally impose a wide variety of administrative duties on the judiciary and thereby enmesh it in legislative affairs. If Congress has directed the judiciary to act through other than the constitutionally prescribed means, the legislation should be invalidated.

\section{b. Formulation of Sentencing Guidelines}

Analogous issues have recently arisen in challenges to the sentencing guidelines promulgated by the United States Sentencing Commission. Under the Comprehensive Crime Control Act of 1984, Congress established a United States Sentencing Commission as an independent agency within the judicial branch. ${ }^{236}$ Congress invested the seven-member Commission, which is to include at least three article III judges, ${ }^{237}$ with the power to issue sentencing guidelines binding upon all federal judges, and, more fundamentally, upon criminal defendants. ${ }^{238}$ Although the guidelines contemplate a range of factors that justify harsher or more lenient punishment, failure to comply with the guidelines will subject a sentencing court to appellate reversal. ${ }^{239}$

Sentencing certainly can be considered a judicial function, and Congress evidently established the Commission within the judiciary in recognition of that historical understanding. ${ }^{240}$ Because sentencing is

23628 U.S.C. $\S 991$ (Supp. IV 1986). Members of the Commission are appointed by the President and are subject to the President's removal authority. Id. § 991(a).

237 Id. Congress rejected a proposal that would have placed the agency solely within control of the Judicial Conference. S. 1182, 98th Cong., Ist Sess., 129 Cong. Rec. S5365 (daily ed. April 28, 1983).

23818 U.S.C. $\S 3553$ (Supp. IV 1986).

239 Id. $\S \S 3553(b), 3742$. Congress made it clear that it intended the guidelines to be mandatory on sentencing judges. See S. Rep. No. 225, 98th Cong., 1st Sess. $79-80$ [hereinafter S. Rep. No. 225], reprinted in 1984 U.S. Code Cong. \& Admin. News 3182, 3262-63. See generally Note, The Constitutional Infirmities of the United States Sentencing Commission, 96 Yale L.J. 1363, 1367-68, 1374-75 (1987) (arguing that mandatory guidelines violate nondelegation doctrine).

240 S. Rep. No. 225 , supra note 239 , at 54, 159, reprinted in 1984 U.S. Code Cong. \& Admin. News at 3342. 
a proper concern for judicial study, the Judicial Conference on its own initiative may issue recommendations on sentencing standards. Furthermore, in the context of particular cases, appellate judges may instruct sentencing judges on the appropriate factors to weigh in reaching sentencing decisions. ${ }^{241}$

The Commission's work, however, is not so anchored; it creates law untethered to any case or controversy. Its actions are therefore justifiable only if they can be considered internal housekeeping matters, analogous to the duties discharged under the Judicial Conduct Act, or if they stem from an inherent source of judicial authority, such as the contempt power.

First, the sentencing guidelines cannot easily be viewed as "housekeeping" measures. To be sure, judges enjoy some inherent authority to prescribe rules to govern practice in their courts, and Congress has long facilitated (and possibly expanded) the exercise of such authority. ${ }^{242}$ In Sibbach v. Wilson \& Co. ${ }^{243}$ for instance, the Supreme Court upheld the validity of a judicial order compelling a party to submit to a physical examination pursuant to Rule 35 of the Federal Rules of Civil Procedure, which was promulgated under the Rules Enabling Act of 1934. ${ }^{244}$ Through the Act, Congress authorized the Supreme Court to prescribe practice in the district courts by general rules as long as such rules did not "abridge, enlarge, []or modify the substantive rights of any litigant."245 The Court sustained the physical examination rule on the ground that it did not modify the litigant's substantive rights, ${ }^{246}$ but merely regulated "the judicial process for enforcing rights and duties recognized by substantive law." 247

241 Federal district courts have so far split on the issue. It has been recently estimated that 140 federal judges have ruled the sentencing guidelines to be unconstitutional, whereas 105 federal judges have upheld the guidelines. Wash. Post, Aug. 30, 1988, at B3, col. 1. In light of such conflicting opinions, the Supreme Court granted certiorari to resolve the issue. United States v. Mistretta, 108 S. Ct. 2818 (1988).

242 See supra note 213 and accompanying text.

243312 U.S. 1 (1941).

244 Pub. L. No. 73-415, 48 Stat. 1064 (current version at 28 U.S.C. $\$ 2072$ (1982)).

245 Id.

246 The Court stressed that a litigant could not be held in contempt for refusing to comply with the physical examination order. Sibbach, 312 U.S. at 16; see Fed. R. Civ. P. 37(b)(2)(D). Sibbach can perhaps best be understood as sanctioning the creation of judicial rules that do not affect the substantive validity of the underlying claim.

247 Sibbach, 312 U.S. at 14. 
Yet sentencing is not a matter of regulating a particular court practice or procedure, but is rather the sine qua non of almost every criminal case. ${ }^{248}$ The aim of the sentencing guidelines is not merely to facilitate litigation in the courts, as with a rule on summary judgment, ${ }^{249}$ but is to determine as a substantive matter the punishment to be meted for given crimes. Thus, the Commission's formulation of sentencing policy cannot be sustained as part of the judiciary's power to prescribe rules governing the practice in its courts.

Second, sentencing cannot be considered inherently judicial. Federal courts can impose sentences only upon congressional direction. ${ }^{250}$ Congress may therefore completely remove judges' discretion from

\footnotetext{
248 See Miller v. Florida, 107 S. Ct. 2446, 2453 (1987) (proscribing retroactive application of a new sentencing law under the ex post facto clause, U.S. Const. art. I, $\S 9, \mathrm{cl} .3$, on the ground that a stiffer sentence "alters a substantial right"); Monessen Southwestern Ry. v. Morgan, 108 S. Ct. 1837, 1842-43 (1988) (holding that measure of recovery is substantive for purpose of adjudication of federal claims in state court). See generally Mishkin, Some Further Last Words on Erie-The Thread, 87 Harv. L. Rev. 1682, 1687 (1974) (arguing that "substantive" limitation in Rules Enabling Act has separation of powers underpinning); Burbank, The Rules Enabling Act of 1934, 130 U. Pa. L. Rev. 1015, 1122-25 (1982) (arguing that Congress intended the Rules Enabling Act to limit the Court's ability to fashion substantive policy that should be articulated instead by Congress).

249 See generally Fed. R. Civ. P. 56 (addressing summary judgment practice). I believe that viewing the case or controversy requirement as a limitation on the judiciary's mode of action calls into question some judicially promulgated federal rules. Through rulemaking, judges acting in their official capacity have fashioned policy that binds litigants other than through cases and controversies. There certainly is no easy way to distinguish between housekeeping rules such as those governing the filing of pleadings, Fed. R. Civ. P. 5., or of caption, Fed. R. Civ. P. 10, and those orders that more clearly address the substantive rights of litigants and establish national policy that should be determined by Congress. Cf. Hanna v. Plummer, 380 U.S. 460, 474-78 (Harlan, J., concurring) (reflecting on difficulties of articulating the distinction between substance and procedure for purposes of the Erie doctrine). I make no attempt to suggest a proper line of demarcation, but whatever line is drawn, the sentencing guidelines almost surely fall on the unconstitutional side of the line.

250 In United States v. Hudson \& Goodwin, 11 U.S. (7 Cranch) 32 (1812), the Supreme Court concluded that the federal courts could not constitutionally exercise jurisdiction over common law crimes. Courts lacked power to mete out punishment until Congress "first ma[d]e an act a crime, affix[ed] a punishment to it, and declar[ed] the court that shall have jurisdiction of the offense." Id. at 34. The question of proper punishment, therefore, rests with the legislative branch. See id.; see also United States v. Worrall, 2 U.S. (2 Dall.) 384 (1798) (opinion of Chase, J.) ("[I]f Congress ever declared and defined the offense, without prescribing a punishment, I should still have thought it improper to exercise a discretion upon that part of the subject."). But cf. People v. Tanner, 24 Cal. 3d 514, 574, 596 P.2d 328, 361, 156 Cal. Rptr. 450, 483 (1979) (en banc) (Bird, C.J., concurring in part and dissenting in part) ("[T]he adjudication and determination of penalty enhancement factors 'are inherently and essentially the province of the court.' "' (quoting People v. Burke, 47 Cal. 2d 45, 52, 301 P.2d 241, 245 (1956))).
} 
sentencing, as it has done for certain offenses in the past. ${ }^{251}$ Indeed, the executive branch has also participated in sentencing through the United States Parole Commission. ${ }^{252}$

Moreover, judges may not perform the administrative duties assigned in the Act merely because the sentencing responsibilities can be characterized as "ancillary" to the judges' proper article III responsibility to impose sentences. There are few administrative responsibilities that cannot be so characterized, ${ }^{253}$ from the pension duties involved in Hayburn's Case to the general administrative duties in Keller v. Potomac Electric Power Co. ${ }^{254}$ Indeed, many would consider advisory opinions to be "ancillary" to the courts' proper role of judicial review.

This is not to deny the special historical relationship between sentencing and the judiciary, ${ }^{255}$ but judges have long exercised near unre-

251 The First Congress, for instance, mandated capital punishment for conviction of treason, murder committed on United States property, piracy, and counterfeiting. See Act of April 30, 1790, 1 Stat. 112, 112-15; see also Act of March 3, 1853, ch. 104, § 4, 10 Stat. 226, 239 (imposing fixed two-year sentence on government employees convicted of embezzlement). Moreover, for a number of years, Congress apparently authorized full appellate review of sentencing. See Act of March 3, 1879, ch. 176, § 3, 20 Stat. 354; see, e.g., United States v. Wynn, 11 F. 57, 57-58 (C.C.E.D. Mo. 1882); Bates v. United States, 10 F. 92, 96 (C.C.N.D. Ill. 1881).

252 See Parole Commission and Reorganization Act, 18 U.S.C. $§ 4205$ (1982 \& Supp. IV 1986) (repealed Nov. 1, 1987); see also Page v. United States Parole Comm'n, 651 F.2d 1083, 1085 (5th Cir. 1981) (rejecting separation of powers challenge to powers of Parole Commission); Moore v. Nelson, 611 F.2d 434, 439 (2d Cir. 1979) (same); Joost v. United States Parole Comm'n, 535 F. Supp. 71, 73-75 (D. Kan. 1982) (same).

${ }^{253}$ Assume instead that Congress directed the Judicial Conference to set attorney's fee schedules under the Civil Rights Act of 1976, 42 U.S.C. § 1988, 28 U.S.C. § 2412(b) (1982 \& Supp. IV 1986). To impose uniformity in awarding fees, the Conference might detail the number of hours that could be awarded in given cases and the maximum fees that would be permissible. Or assume that Congress directed the Conference to set binding merger guidelines to make judicial proceedings in antitrust cases more manageable. Both functions could be considered ancillary to article III functions, and indeed, courts have historically adjudicated issues in both contexts and thereby gained considerable expertise in the areas. See, e.g., Pennsylvania v. Delaware Valley Citizens' Council for Clean Air, 107 S. Ct. 3078 (1987) (addressing calculation issues in attorney's fee determinations under the Civil Rights Act of 1976); Hensley v. Eckerhart, 461 U.S. 424 (1983) (same); United States v. General Dynamics Corp., 415 U.S. 486 (1974) (addressing propriety of mergers under antitrust law); United States v. Philadelphia Nat'l Bank, 374 U.S. 321 (1963) (same). The Conference's exercise of such functions, however, could not be reconciled with the case or controversy limit on judicial action.

254261 U.S. 428 (1923); see supra note 202.

255 Furthermore, if the administrative functions are permissible only because of the special relationship between the judiciary and sentencing, it is difficult to defend Congress's decision 
viewable discretion in other contexts as well. ${ }^{256}$ Trial court judges today enjoy comparable latitude in assessing punitive damages in nonjury cases. ${ }^{257}$ Such leeway does not permit other judges (or officials within the judiciary) to constrain that discretion through promulgation of binding rules setting a scale of permissible punitive damage awards in given contexts. Similarly, the sentencing standards developed by the Commission represent policy judgments that cannot be justified as ancillary to the judiciary's article III function of imposing sentences. $^{258}$ The discharge of such administrative authority is

to place the Commission outside the control of article III judges. Congress determined that the Commission need not be composed primarily of article III judges, and it provided that the President exercise removal power over all members of the Commission. Thus, the sentencing enactment is inconsistent with the special relationship between trial court judges and the sentencing decision.

256 If exercise of broad discretion were the touchstone for judicial discharge of administrative tasks, Congress could delegate wide areas of administrative or "executive" authority to the judiciary, merely by following the expedient of first vesting wide discretion in trial court judges.

257 See Muratore v. M/S Scotia Prince, 845 F.2d 347, 354 (1st Cir. 1988).

258 Judicial participation on the Sentencing Commission cannot easily be characterized as voluntary service at the behest of the executive branch. Unlike in the Organized Crime Commission cases, see supra note 204, Congress has mandated that at least three article III judges serve on the Commission. If the Commission is in the executive branch, then Congress effectively has removed three judges from hearing cases and controversies-a somewhat disturbing precedent. See Hastings v. Judicial Conference of United States, 770 F.2d 1093, 1108 (D.C. Cir. 1985) (Edwards, J., concurring) (noting potential separation of powers violation where Congress authorizes the removal of a judge from hearing cases), cert. denied, 477 U.S. 904 (1986). More fundamentally, although no particular judge is compelled to exercise such tasks, the judiciary as an institution is left no choice but to staff the positions on the Commission. The fact that Congress requires article III judges to serve on the Commission strongly suggests that Congress intended judges to act in their judicial capacity, and not strictly as volunteers, when serving on the Commission. Presumably, were Congress to create an Advisory Opinion Commission, composed of nine article III judges willing to perform such functions, a separation of powers problem would arise irrespective of the voluntariness of each judge's participation. The case or controversy limitation protects the judiciary as an institution from becoming entangled in the affairs of coordinate branches of government, and it defines how each judge can act in a judicial capacity.

If, despite the element of congressional compulsion, the judges' participation is considered voluntary, then a different separation of powers issue is raised, because the case or controversy requirement does not directly constrain such voluntary, nonjudicial action. The question would then become, as in the Organized Crime Commission cases, whether the judges' service in the executive branch would compromise the judicial branch by aligning the judges too closely with the executive. If judges, when serving voluntarily in the executive branch, can promulgate binding rules which other judges must then both evaluate and apply, the appearance-and perhaps even the reality-of impartiality may be threatened. In any event, the question can only be resolved by means of a rough accommodation of interests. See supra 
unchecked in a constitutional sense and would usurp the policymaking role reserved to Congress or its delegate in the executive branch.

The case or controversy limitation recognizes that the judiciary is largely unaccountable for its actions and therefore confines it to one permissible mode of action. The judiciary will less likely encroach upon the coordinate branches of government, as well as on individual rights, if it can act only in properly constituted cases and controversies. Upholding the Sentencing Commission would therefore sanction a glaring departure from the case or controversy limitation on judicial action.

In sum, the case or controversy requirement marks the boundary of the judiciary's power in our system of separated powers. Just as the bicameralism, presentment, and appointments clause provisions restrict the authority of Congress and the executive, the article III limitations confine the judiciary. Efforts to vest the judiciary with greater power-whether through acts of Congress, requests of the President, or judicial instigation-should therefore be invalidated regardless of the potential political benefits such arrangements could bring. The constitutional structure presupposes that, over time, insulating the judiciary from too great an involvement in the political affairs of its coordinate branches best preserves judicial independence and individual liberty.

\section{A BRIEF LoOK AT the INDEPENDENT Counsel Decision}

At first blush, the recent Supreme Court decision in the independent counsel case, Morrison v. Olson, ${ }^{259}$ seems strikingly inconsistent with the structural approach to separation of powers controversies followed in Bowsher and Chadha. Despite the executive's claims of congressional and judicial encroachment on its core article II power of criminal law enforcement, the majority engaged in a flexible balance to uphold the statutory scheme. Unlike the executive assertions in Chadha and Bowsher, those raised in Morrison appeared to receive short shrift. The inconsistency among the cases, however, is more apparent than real.

note 204. Thus, viewing the Sentencing Commission as part of the executive branch, aside from departing from congressional intent, may not satisfy all the constitutional concerns.

259108 S. Ct. 2597 (1988). 
Under the Ethics in Government Act of 1978 ("Ethics Act"), ${ }^{260}$ the Attorney General may apply for appointment of an independent counsel to investigate and prosecute high-ranking government officials and other individuals whose investigation by the Department of Justice might otherwise place officers of the Department of Justice in a conflict of interest. ${ }^{261}$ The Act directs the Attorney General, upon receipt of credible information that such a person has engaged in criminal activity, to conduct a preliminary investigation into the matter within ninety days. To secure appointment of an independent counsel after the preliminary investigation, the Attorney General must apply to a specially created division of the United States Court of Appeals for the District of Columbia Circuit. ${ }^{262}$

The special division then must both appoint an independent counsel and define the counsel's jurisdiction. ${ }^{263}$ The court has the continuing responsibility to determine whether the scope of that jurisdiction should be modified. ${ }^{264}$ If the court determines on its own motion that the work of the independent counsel has been "so substantially completed that it would be appropriate for the Department of Justice to complete such investigations and prosecutions," ${ }^{, 65}$ it may terminate the independent counsel's office.

In moving to quash subpoenas issued by the grand jury under the authority of the independent counsel, three former officials of the Department of Justice challenged the Act on several separation of powers grounds. They argued in part that judicial appointment of the independent counsel violated the appointments clause, that the Act's delegation to the special court of the power to define the independent counsel's jurisdiction and to terminate the office violated article III of the Constitution, that the Act's restriction on the Attorney General's ability to remove the independent counsel undermined the concept of a unitary executive, and, finally, that the Act as a whole impermissibly interfered with the executive's prerogative to enforce the criminal laws. The Department of Justice, as amicus curiae, also urged the court of appeals to invalidate the Act. The court of appeals agreed

26028 U.S.C. $\S \S 591-598$ (1982 \& Supp. IV 1986).

261 Id. § 591(b)-(c) (1982).

262 Id. § 392(c) (1982); see id. § 49 (1982 \& Supp. 1986).

263 Id. § 593(b) (1982).

264 Id. §§ 593(c), 594(e).

265 Id. § 596(b)(2). 
with the above arguments and struck down the statute. ${ }^{266}$

Nonetheless, the Supreme Court's decision rejecting the constitutional challenges generally tracks the two-tiered analysis presented in this Article. Unlike the disputed congressional roles in Bowsher and Chadha, the role exercised by Congress in Morrison is constitutionally unobjectionable. ${ }^{267}$ Both houses of Congress agreed on the independent counsel legislation and presented it to the President for his approval. The majority's opinion is therefore consistent with the balancing approach taken in Nixon and in Schor. ${ }^{268}$ After assessing the potential incursion on the executive's law enforcement prerogatives, the majority concluded that, although "[i]t is undeniable that the Act reduces the amount of control or supervision that the Attorney General ... exercises over the investigation and prosecution of a certain class of alleged criminal activity," the executive retains "sufficient control over the independent counsel to ensure that the President is able to perform his constitutionally assigned duties."269

In dissent, Justice Scalia criticized the majority's ad hoc approach to resolving the separation of powers issues in the case. He asked, "What are the standards to determine how the balance is to be struck, that is, how much removal of presidential power is too much?"270 Balancing, to Justice Scalia, was wholly inappropriate because "it is ultimately irrelevant how much the statute reduces presidential control. . . . It is not for us to determine . . . how much of the purely executive powers of government must be within the full control of the President. The Constitution prescribes that they all are."271 He concluded that the majority's reliance on balancing resulted in "the folly

266 In re Sealed Case, 838 F.2d 476, 481-88, 511-18 (D.C. Cir. 1988) (two-to-one decision), rev'd sub nom. Morrison v. Olson, 108 S. Ct. 2597 (1988).

267 The majority distinguished Bowsher on the ground that Morrison did "not involve an attempt by Congress itself to gain a role in the removal of executive officials" and, therefore, "simply does not pose a "dange[r] of congressional usurpation of Executive Branch functions." " Morrison, 108 S. Ct. at 2616, 2620 (quoting Bowsher, 478 U.S. at 727). That distinction, much like the analysis proposed in this Article, focuses on the mode of congressional power, not on its magnitude. A different question would arise, of course, if Congress vested prosecutorial authority in its own agent.

268 Justice Rehnquist's opinion for the Court in Morrison, however, is inconsistent with his dissenting opinion in Nixon. See supra note 130.

269 Morrison, 108 S. Ct. at 2621-22.

270 Id. at 2629 (Scalia, J., dissenting).

271 Id. at 2628. 
of the new system of standardless judicial allocation of powers."272

Some balancing, however, was unavoidable. Congress's power under article I surely encompasses the power to specify the means that the executive must employ in enforcing the criminal laws. Justice Scalia could not conceivably argue that any reduction in the executive's current control over criminal prosecution is unconstitutional. Historically, Congress has fragmented control over criminal law enforcement within the executive branch, ${ }^{273}$ withheld funds requested by the administration, ${ }^{274}$ and vested some investigative and prosecutorial authority in state officials and private individuals outside the control of the executive. ${ }^{275}$ Although not structured in this manner, the majority opinion correctly determined that, in this instance, some balancing was required to determine whether Congress's exercise of the power to shape criminal law enforcement undermined the constitutional imperative of the unitary executive. ${ }^{276}$

In contrast, balancing was not similarly appropriate in resolving the separation of powers issue posed by the special court's power to define the independent counsel's jurisdiction and to terminate the counsel's office. In effect, Congress, through the Ethics Act, has assigned the special court a policymaking role in determining whether, or to what extent, to modify the Attorney General's original

272 Id. at 2631.

273 See generally A. Langeluttig, The Department of Justice of the United States (1927); L. White, The Federalists: A Study in Administrative History (1948); Key, The Legal Work of the Federal Government, 25 Va. L. Rev. 165 (1938). Congress plainly could have removed the office of independent counsel totally from the Department of Justice. District attorneys for the first years under the Constitution were not subject to the Attorney General's direction. See L. White, supra, at 166; 1 Op. Att'y Gen. 608, 609-11 (1823) (Opinion of William Wirt, refusing to respond to an inquiry from a district attorney). But see Morrison, $108 \mathrm{~S}$. Ct. at 2626-31 (Scalia, J., dissenting) (stressing importance of centralized criminal law enforcement).

274 L. White, supra note 273, at 168; Key, supra note 273, at 176.

275 See generally J. Jacoby, The American Prosecutor: A Search for Identity (1980) (discussing role of private individuals in federal criminal law enforcement); Warren, Federal Criminal Laws and the State Courts, 38 Harv. L. Rev. 545, 551-75 (1925) (canvassing early instances in which Congress vested criminal jurisdiction in state courts and auxiliary law enforcement duties in state officials).

276 Even under a general balancing approach, however, one could conclude that vesting prosecutorial authority in an officer shielded from the President's removal authority is per se unconstitutional. In other words, balancing tests need not always be resolved on a case-bycase basis, but can extend to a class of cases. Compare Morrison, 108 S. Ct. at 2621 ("Congress' role under the Act is [adequately] limited.") with id. at 2630 (Scalia, J., dissenting) ("[E]ven as an ad hoc, standardless judgment the Court's conclusion must be wrong."). 
grant of jurisdiction to the independent counsel. ${ }^{277}$ Moreover, the power to terminate the office of independent counsel is also removed from exercise of the judicial function. Determining whether an investigation is "substantially complete" obviously gives the court influence over the independent counsel. An independent counsel is aware that the court could impose "the drastic remedy of terminating the office" 278 when it believes that the counsel "is attempting to prolong his office beyond the time it is really needed."279 The court therefore supervises the prosecution not in order to resolve a case or controversy, but to ensure that the independent counsel is accountable for his or her conduct.

Indeed, the majority appeared to hesitate before applying a balancing test when analyzing the duties assigned to the judiciary under the Ethics Act. The majority acknowledged that "we have broadly stated that 'executive or administrative duties of a nonjudicial nature may not be imposed on judges holding office under Art. III of the Constitution." "280 Although not acknowledged by the majority, such a rule is inconsistent with a balancing test because even if the nonjudicial administrative duties vested in the judiciary pose only a modest threat of intruding into a coordinate branch of government, the duties presumably are still invalid. Otherwise, the results in Hayburn's Case ${ }^{281}$ and in Keller v. Potomac Electric Power Co. ${ }^{282}$ make little sense, because the courts in those cases never determined that the administrative schemes presented any realistic threat to the allocation of powers.

277 The Senate Report emphasized that defining "[t]he prosecutorial jurisdiction of the special prosecutor is one of the most important devices for the control of the special prosecutor and the accountability of such a special prosecutor." S. Rep. No. 170, 95th Cong., 1st Sess. 56, reprinted in 1978 U.S. Code Cong. \& Admin News 4217, 4272. The Senate Report in fact stated that "even if the Attorney General should not request that related matters be assigned to an existing special prosecutor, the court has the authority to do so," and it stressed that "the court's responsibility in defining the prosecutorial jurisdiction of [an independent counsel] is a continuing one." Id. at 65, reprinted in 1978 U.S. Code Cong. \& Admin News at 4281.

278 Id. at 75, reprinted in 1978 U.S. Code Cong. \& Admin. News at 4291.

279 H.R. Rep. No. 1307, 95th Cong., 2d Sess. 11 (1978). As the court of appeals noted, a "determination that an investigation should end is a subtle one often requiring as much selfconfidence and courage as close legal analysis." In re Sealed Case, 838 F.2d 476, 515 (D.C. Cir. 1988), rev'd sub nom. Morrison, 108 S. Ct. at 2597.

280 Morrison, 108 S. Ct. at 2612 (quoting Buckley v. Valeo, 424 U.S. 1, 123 (1976)).

2812 U.S. (2 Dall.) 409 (1792); see supra notes 191-202 and accompanying text.

282261 U.S. 428 (1923); see supra note 202; supra note 254 and accompanying text. 
The majority circumvented the need to establish a test for assessing the special court's authority to define the independent counsel's jurisdiction because it upheld that authority as an incident to the judiciary's appointment power under article II. As framed by the Court, the only relevant question concerned whether the court's responsibility to define jurisdiction was "incidental" to the appointment power. ${ }^{283}$ Judicial exercise of a constitutionally based power, such as authority under the appointments clause, need not conform to the case or controversy requirement. ${ }^{284}$

The majority, however, could not avoid addressing the special court's power to terminate the office of the independent counsel. Although asserting that it was "more doubtful" about that power, it appeared to adopt an implicit balancing test in concluding that the power to terminate did not represent "a significant judicial encroachment upon executive power or upon the prosecutorial discretion of the independent counsel."285

If balancing were appropriate, the question raised by the court termination provision should have been easy to resolve. Plainly, Congress has substantial interest in ensuring that a "runaway" investigation by an independent counsel be stopped. Individuals subject to such an investigation, as well as the public at large, can benefit by judicial oversight. Although there may be some intrusion on executive branch prerogatives, such harm is difficult to quantify and likely to pale when balanced against the articulated congressional interest at stake.

The power to terminate an office, however, does not stem from the judicial duty of deciding cases and controversies. Rather, it involves determinations implicating prosecutorial policy and allocation of resources, determinations for which the judiciary is wholly unac-

283 Morrison, 108 S. Ct. at 2613.

284 Of course, as a matter of substantive constitutional law, some would disagree with the Court's characterization of the power to define the independent counsel's jurisdiction as an incident of the appointment power. The President's appointment of article III judges certainly does not carry with it the power to define the judges' duties.

285 Morrison, $108 \mathrm{~S}$. Ct. at 2614. The majority agreed that a "narrow construction is appropriate" to avoid the more serious constitutional question that would be raised if the termination provision were construed broadly to give the special court supervisory authority over the independent counsel. Id. 
countable. Perhaps, despite the court of appeals's characterization, ${ }^{286}$ that power can be viewed as de minimis or purely ministerial. But the balancing undertaken by the majority obscures the fact that the constitutional restraints on judicial action serve, in the long run, to preserve the independence of the judiciary and to protect individual liberty. The separation of powers doctrine ensuing from such indiscriminate balancing will conform to the constitutional framework only by chance.

\section{CONCLUSION}

By delineating the mode in which each branch may act, the Constitution promotes accountability and strives to preserve a balance among the three governmental powers. Demanding compliance with these internal checks therefore furthers the values enshrined in the separation of powers doctrine.

To be sure, the allocation of powers has shifted dramatically in the two hundred years since the Constitution was ratified. Everyone would agree that the changes have favored the executive branch at Congress's expense. Some have even termed this an era of imperial presidency. ${ }^{287}$ In the face of such developments, strictly limiting the powers of Congress and the judiciary may appear misguided at best.

Nonetheless, a continued focus on accountability remains essential. Circumscribing the ways each branch may act serves not only to maintain a balance among the branches, but also to preserve individual liberty. Enforcing the procedural restraints should, in turn, minimize conflict among the branches.

These restraints on action apply not only to Congress but also to the executive branch and the judiciary, albeit in different ways. Because each branch has ample means to preserve its own independence and to resist encroachments from the other branches, the executive's accretions of power, though understandable, are not inevitable. Indeed, except for a possible reservoir of power in the foreign affairs arena, the executive depends largely upon Congress for its authority.

\footnotetext{
${ }^{286}$ See In re Sealed Case, 838 F.2d 476, 515 (D.C. Cir. 1988) ("This Special Court then holds over the head of the independent counsel both the broadsword and the rapier to control the pace and depth of the independent counsel's activities."), rev'd sub nom. Morrison, $108 \mathrm{~S}$. Ct. at 2597.

287 See A. Schlesinger, The Imperial Presidency (1973); Schlesinger, The Constitution and Presidential Leadership, 47 Md. L. Rev. 542 (1987).
} 
Thus, demanding accountability from Congress in particular does not compel legislative acquiescence to executive hegemony; rather, fidelity to the internal checks in the Constitution ensures a due process of lawmaking. 
HeinOnline -- 74 Va. L. Rev. 13241988 